NBER WORKING PAPER SERIES

DISEASE CONTROL, DEMOGRAPHIC CHANGE AND INSTITUTIONAL DEVELOPMENT IN AFRICA

\author{
Margaret S. McMillan \\ William A. Masters \\ Harounan Kazianga
}

Working Paper 19245

http://www.nber.org/papers/w19245

\author{
NATIONAL BUREAU OF ECONOMIC RESEARCH \\ 1050 Massachusetts Avenue \\ Cambridge, MA 02138 \\ July 2013
}

We are grateful to the NBER African Successes Project and IFPRI for financial support, and thank Moussa Kabore and colleagues in the Direction de la Prospective et des Statistiques Agricoles et Alimentaires (DPSAA) of Burkina Faso for survey implementation, as well as Jose Castillo, Inigo Verduzco and Jun Folledo for research assistance, Rohini Pande and Remi Jedwab for comments on an earlier draft, and Bruce Benton for detailed information about the history and operations of the OCP. This paper has been much improved by valuable suggestions from the editor and referees as well as Will Dow and other participants at the Zanzibar Conference of the NBER African Successes Project, August 3-5, 2011. The views expressed herein are those of the author and do not necessarily reflect the views of the National Bureau of Economic Research.

NBER working papers are circulated for discussion and comment purposes. They have not been peerreviewed or been subject to the review by the NBER Board of Directors that accompanies official NBER publications.

(C) 2013 by Margaret S. McMillan, William A. Masters, and Harounan Kazianga. All rights reserved. Short sections of text, not to exceed two paragraphs, may be quoted without explicit permission provided that full credit, including $\odot$ notice, is given to the source. 
Disease Control, Demographic Change and Institutional Development in Africa

Margaret S. McMillan, William A. Masters, and Harounan Kazianga

NBER Working Paper No. 19245

July 2013

JEL No. I00,Q0,Q00

\begin{abstract}
$\underline{\text { ABSTRACT }}$
This paper addresses the role of tropical disease in rural demography and land use rights, using data from Onchocerciasis (river blindness) control in Burkina Faso. We combine a new survey of village elders with historical census data for 1975-2006 and geocoded maps of treatment under the regional Onchocerciasis Control Program (OCP). The OCP ran from 1975 to 2002, first spraying rivers to stop transmission and then distributing medicine to help those already infected. Controlling for time and village fixed effects, we find that villages in treated areas acquired larger populations and also had more cropland transactions, fewer permits required for cropland transactions, and more regulation of common property pasture and forest. These effects are robust to numerous controls and tests for heterogeneity across the sample, including time-varying region fixed effects. Descriptive statistics suggest that treated villages also acquired closer access to electricity and telephone service, markets, wells and primary schools, with no difference in several other variables. These results are consistent with both changes in productivity and effects of population size on public institutions.
\end{abstract}

Margaret S. McMillan

Tufts University

Department of Economics

114a Braker Hall

Medford, MA 02155

and International Food Policy Research Institute $\mathrm{m}$ mس山س山m mharounan.kazianga@ okstate.edu and also NBER

margaret.mcmillan@tufts.edu

William A. Masters

Tufts University

Department of Food and Nutrition Policy

150 Harrison Avenue

Boston, MA 02111

william.masters@tufts.edu

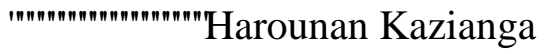

एس山ा

एس山ा

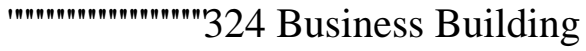

एाس 


\section{Disease Control, Demographic Change and Institutional Development in Africa}

\section{Introduction and Motivation}

In 1974, the World Health Organization and numerous partners launched the Onchocerciasis Control Program in West Africa. The OCP extended across Côte d'Ivoire, Niger, Mali, Togo, Benin, and Ghana and was centered on Burkina Faso (then Upper Volta), where the disease had infected about 10 percent of the population. New infections occurred primarily among rural children south of the $13^{\circ}$ parallel, through painful bites from the aptly named Simulium damnosum blackfly carrying the microfilarial larva of a parasitic worm, Onchocerca volvulus. Those infected experienced itching, disfigurement, and eventual blindness. The blackfly vector can reproduce only in the oxygenated waters of a river or stream, hence the common name of this disease -- river blindness - and the potential for intervention to have a large economic impact by facilitating settlement in otherwise productive river valleys.

To control the disease, starting in 1975 the OCP used helicopters to spray larvacide along rivers. The vector began to disappear by 1977 , enabling people to move closer to rivers without fear of blackfly bites and new Onchocerciasis infections. The vector-control phase of OCP ended in 1989, after which the OCP focused on the distribution of ivermectin to control symptoms in those already infected. Ivermectin had been a veterinary deworming drug, which in the early 1980s was also shown to be effective in killing the microfilariae produced by Onchocerca in the human body. Adult worms are not affected, but ivermectin blocks their reproduction until they reach the end of their natural lifespan about 14 years after infection.

Distribution of ivermectin to help villagers with Onchocerciasis began in 1987. Annual doses successfully controlled symptoms of the disease and prevented further transmission of the Onchocerca parasite. The blackfly vector returned to the river valleys but the disease was no longer endemic and in 2002 the OCP ended, with ivermectin remaining in use against filarial parasites transmitted by other channels.

The OCP is widely recognized to have been one of the world's most successful public health projects (Levine 2007). Figure 1 illustrates the remarkable extent to which Onchocerciasis 
was brought under control across West Africa between 1975 and 2002, with near-eradication in many places and continued endemicity only in Sierra Leone where the OCP was not active. How the OCP discovered and implemented their approach has been the subject of many studies in tropical medicine (e.g. Benton et al. 2002) and a widely read book in anthropology (McMillan 1995).

In this paper, we use OCP exposure and associated changes in village population to address the role of public health in local institutions' provision of agricultural property rights, with additional data on changes in public services and infrastructure. Disease control could influence local institutions directly by changing the productivity of labor, land and capital, and could also matter via its effects on rural population size and density. The role of population density was emphasized by Boserup (1965), who argued that a larger rural population creates new incentives for institutional change and collective action, in addition to new incentives for induced innovation and technological change as had been suggested by Hicks (1932). Boserup's hypothesis could operate through scale effects from population size, relative-price effects from factor scarcity, or both.

Modern analyses of how rural demography affects agricultural development were pioneered by Hayami and Ruttan (1971) for the U.S. and Japan, and tested in a large subsequent literature such as Johnston and Kilby (1975) and Olmstead and Rhode (1993). Only a few of these papers (e.g. Lin 1995) focus on the emergence and adoption of institutions; most ask how institutions affect technology adoption, such as Kazianga and Masters (2002, 2006). Focusing on rural demography also expands on our other previous work regarding the role of environmental factors in economic growth (Masters and McMillan 2001) and African policy choices (McMillan 2001, McMillan and Masters 2003).

Our focus on the specific challenge of rural population growth contrasts with most study of demography in development economics, which has focused either on demographic transition in the population as a whole (including the demographic "drag" or "dividend" from age structure emphasized by Bloom and Williamson, 1998), or the structural transformation from farm to nonfarm employment in terms of output and employment shares (including the "growth bonus" associated with shifting from a low productivity to a high productivity sector as in Temple, 2005). Focusing on demographic conditions within rural areas addresses Africa's distinctive 
history of post-independence agricultural decline, and grounds for optimism about the future as rural infrastructure and institutions adapt to higher levels of rural population density.

Studying how rural Burkina Faso responded to the OCP offers an opportunity to extend the broader literature on the economic effects of public health shocks (Acemoglu and Johnson 2007, Cutler et al. 2010, Bleakley 2007, Ashraf, Lester and Weil 2009) and demographic change more generally (Galor 2012, Galor and Weil 1999). Our study is made possible by the timing of Burkina Faso's decennial censuses in 1975 (before vector control) and 1985 (before deworming), then 1996 and 2006 (after the disease was fully controlled). We focus on OCP-related variation in village population, in land-use rights and various public amenities, as recalled by focus group interviews of village elders.

The closest antecedent to our study is probably Grimm and Klasen (2008), who test for endogenous adoption of land titles at the village level on Sulawesi in Indonesia, but we address a wider range property rights and also include data on a variety of other public services and infrastructure. Methodologically, our use of focus groups to obtain village-level recall data on institutional arrangements and public amenities follows Chattopadhyay and Duflo (2004), building on a long tradition of participatory surveys in rural areas (e.g. Chambers 1994). This approach allows us to ask about many different types of property rights, public services and infrastructure, as seen from the villagers' point of view.

One purpose of this paper is to test the value of villagers' recall data in establishing stylized facts about how the actions of public institutions vary across space and time. In future work, recall data of this type could also be used to analyze causal effects of public services, infrastructure and property rights on economic outcomes. For example, Besley (1995) found evidence that institutions significantly affect investment outcomes in rural Africa. Pande and Udry (2006) provide a summary of these studies. In Burkina Faso specifically, Kazianga and Masters (2002) found that stronger cropland tenure was associated with more intensive soil and water conservation.

In the next section, we describe how OCP treatment affected rural Burkina Faso, before turning to our own empirical strategy, data and results. 


\section{Onchocerciasis Control and Population Movements in Burkina Faso}

River blindness is spread through bites from a blackfly that reproduces in rivers and subsists on human blood, transmitting the filarial larvae of a parasitic worm. These larvae develop into adult worms inside the body, forming nodules typically around the waist area, where they live for about 14 years and produce millions of microfilariae that move to and damage the victim's skin and eyes. The microfilariae themselves have a lifespan of up to two

years in the human body, during which time they may be ingested by another blackfly, hosted for 6-8 days and transmitted to another person.

The blackfly can reproduce only in rivers and streams, from which they fly for many miles to take human blood meals. When the human population in that vicinity is sufficiently dense, these blackfly bites are painful but no transmission occurs because the fraction of blood meals containing microfilariae is too low to sustain the Onchocerca population. When humans are present in population in the blackfly at lower density, the disease becomes hyper-endemic. Children will become infected soon after they begin to move outside the home, skin disfiguration occurs in the late teens, and eyesight deteriorates in adulthood. When transmission through the blackfly is interrupted, those infected become cured when the adult worms eventually die, and their symptoms can be relieved in the meantime by treatment with ivermectin.

In the southern parts of Burkina Faso where blackflies could carry Onchocerciasis, only a small fraction of locations had a sufficiently high human population density to prevent transmission before the OCP began. An analysis of the country's 1975 census suggested that high densities would have protected people around the capital city, Ouagadougou, and along a corridor $150 \mathrm{~km}$ from there northwest to Ouahigouya and southeast down to the Nazinon Valley on the border with Ghana. Soon after spraying started in 1975, people responded by spreading out into the newly attractive river valleys, expanding existing villages and also starting new ones. Some of this movement was spontaneously undertaken by individuals, and some of it occurred through planning in villages targeted for settlement by a government agency, the Autorité des Aménagements des Vallées des Volta (AVV).

The demographic changes that followed immediately after OCP intervention are illustrated in Figure 2, showing population growth rates for 1975-1985 in our nationally representative sample of villages. The map shows the location of Burkina Faso's major rivers, 
with shading in the areas where pre-intervention surveys found the parasite to be endemic so OCP spraying occurred. Symbols for each village indicate its population growth rate between the 1975 and 1985 censuses, using triangles for villages in AVV areas, and dots for villages that were not part of AVV planning. Visual inspection suggests clear differences in growth rates between villages in the shaded and non-shaded regions, with most villages in the treated areas experiencing ten-year population growth exceeding 75 percent, and most villages elsewhere experienced growth of less than 50 percent.

The pattern of migration in response to OCP spraying is described in detail by McMillan et al. (1992, 1993). Some of this occurred from the drier and higher-altitude northeast and central plateau into the Onchocerciasis zone, while some involved movement within the zone closer to rivers where blackfly bites had been more frequent, transmission rates higher and parasite loads heavier. Some settlement was linked to AVV planning and investments, but McMillan et al. (1993) estimate that more than 80 percent of the increase in cultivated land in Burkina's river basins could be attributed to spontaneous settlers outside of AVV influence.

\section{Data Sources, Sample Selection and Descriptive Statistics}

Our evidence on changes in villages' institutional arrangements and public amenities comes from a novel survey conducted for this project by the Burkina Faso Office of Agricultural Statistics in January through June 2010. This survey asked groups of village elders to discuss and describe the history of their property rights and access to various amenities, recording the year in which any changes occurred. From those underlying observations, we construct time-varying indicators of villagers' property rights over land and their proximity to each kind of public service or infrastructure. We combine these measures with geocoded data on the boundaries of OCP treatment and AVV planning areas, plus population estimates for each village from the four national censuses of 1975, 1985, 1996, and 2006, to estimate the impact of exposure to treatment on village population size, property rights and local institutions' provision of public services and infrastructure.

The actual questionnaire for the group interviews is reproduced in an online appendix. The survey was administered by experienced enumerators employed for the country's annual agricultural survey. For our interviews, enumerators assembled a focus group of village leaders 
to ask about various types of property rights and public services. In each case the goal was to characterize the village's current situation and when it arose, what preceded it and when that came to be, and what had been the earlier situation and when it was established. We recorded up to three changes in each kind of institution or service, and registered responses only when consensus was achieved. For example, we asked: Are there forest areas around your village? And if yes, we asked: Is there a restriction on use of these forest areas? We offered multiple choices, such as taxes, payments or limits on removal of products or entry to the forest for various kinds of users, or the option of "no restriction". We asked for the year in which any restriction (if any) was imposed, what restrictions had been in place earlier and when they were introduced. In each case, we deliberately provided no anchor dates and no indication that responses would be analyzed in relation to village population or Onchocerciasis control.

Questions posed in this way allow us to construct time varying indicators from the point of view of the villagers themselves. For this paper we use only binary variables for each of the four census years, for example whether any forest-use restriction was in place, but the technique could potentially be used for richer characterizations of historical changes. Also, the hypothesis tests in this paper focus on changes in property rights over cropland, pasture and forests, but we also present descriptive information on public services and infrastructure such as primary schools, bus stops and livestock markets. For each of various amenities we asked the group how far villagers currently travel to reach the nearest point of service and when that amenity became available at that location; how far they had to travel for that in earlier years and when it became available there; and again how far the amenity had been from the village before that and when it became available there.

Our questionnaire asked for current and historical indicators of 18 different indicators of land-use rights, and for current and historical distances to a total of 32 different kinds of public goods, services and markets. Questions were pre-tested by the Ministry of Agriculture enumerators, and terminology was back-translated to ensure correspondence between economic concepts and local usage. For example, in asking about property rights over pasture and the gradual enclosure of grazing areas, we constructed a categorical variable classifying ownership as being vested in an individual, as opposed to a family, a lineage, or a community. Our question about access to rural banking concerns the nearest Caisse Populaire branch. As expected, 
questions varied in the degree to which respondent groups were able to agree on an answer. In the end we retained data for 21 public amenities and 5 kinds of property rights which many village groups could recall back to 1975 or beyond.

The entire sample of farm households used by the Office of Agricultural Statistics for its nationally-representative surveys consists of 747 villages. Of these, we drop 118 villages because they are located in areas subject to AVV planning, where land use rights and public amenities are unlikely to be representative of the country as a whole. An additional 14 villages had to be dropped because of uncertainty in matching our survey villages to census data and OCP maps, due either to differences in village names as recorded in agricultural statistics and in the census, or to errors in recording GIS coordinates. Our final sample size is 615 villages, of which 60 percent are located in the Onchocerciasis-endemic areas that received treatment. Over threefourths of the final sample (a total of 473 villages) had their population recorded in all four census years. An additional 131 villages had their population recorded in three of the four years, and only 11 villages have population data for only two of the four years. Our preferred specification pools the data for all 615 villages in an unbalanced panel, so that our results are nationally representative of the average village observed in 2006 everywhere in the country outside of AVV planning zones. As a robustness test for internal validity we compare these results to those obtained using only the subset of 473 villages whose population data forms a balanced panel. Those results, available on request, are substantially identical to those shown here. Both parameter estimates and significance levels are very similar, and in almost all cases where significance differs the estimates are more precise when using the smaller balanced sample, but in any case the larger sample is preferred to avoid the reverse-attrition bias that would arise if we did not include villages formed after 1975, perhaps as a result of OCP treatment.

Descriptive statistics on all variables used in our final regressions are shown in Table 1, and differences at baseline between villages in treated and untreated areas are shown in Table 2. The first column of Table 1, Panel A shows average village populations to have grown from 1975 to 1986, then changed little in the decade from 1986 to 1996, and become smaller in 2006 with a much larger standard deviation. Differences between average village size and aggregate population growth could be due to migration and formation of new villages, and also the 
possibility of measurement error especially in the 2006 census. Regarding property rights, we find that land use arrangements became slightly more market oriented in each successive census year. For example, the share of observations in which cropland rights were assigned to individuals as opposed to families, lineages, communities (or remaining unassigned) rose from 38 percent in 1975 to almost 44 percent in 2006. The largest changes were for regulation of pasture and forest use, which rose from 23 to 43 percent and from 1 to 17 percent of villages respectively. The occurrence of land transactions and permit requirements prior to transactions both became slightly more widespread, from 85 to 89 and from 34 to 37 percent of villages respectively, but standard deviations are quite large relative to those trends.

Panel B of Table 1 shows descriptive statistics for public amenities. Most of these came to be provided increasingly close to villages, but the first column of Panel B shows villages' mean distance to the closest road to have risen from $3.79 \mathrm{~km}$ in 1975 to $4.91 \mathrm{~km}$ in 1996, before dropping again in 2006. This could have been due either to new villages being formed far from existing roads, or old roads becoming impassable due to lack of maintenance, until accelerated road-building brought the average village back towards the proximity enjoyed in 1975. The amenity whose proximity changed the most is primary schools, whose mean distance from the village declined by an order of magnitude, from about 11 to about $1 \mathrm{~km}$ over the 1975-2006 period. Distances to secondary schools, health clinics, private shops and water wells or boreholes also declined sharply to a third of their 1975 value, while several others declined to about half. Average distances to the nearest livestock market and irrigation dam changed very little relative to standard deviations, which reveal wide variation across villages in their degree of remoteness.

Comparing the subsamples at baseline in Table 2, prior to disease control the villages in treated areas were considerably smaller than other villages, less likely to have individual rights over crop land and more likely to require permits for land transactions. They were farther from banking services, electricity or landline telephone service, public markets, livestock markets, dams and schools. None of the public amenities were closer to villages in OCP areas than elsewhere. Our regressions ask whether disease control helped the Onchocerciasis-affected areas catch up and perhaps even surpass other parts of the country in village sizes and property rights. Comparing the subsamples at the end of our time period shows fewer significant differences: in 2006 there was no longer any significant difference between treated and control areas in village 
population, whether a permit was required for land transactions, or the distance to landline telephones, public markets or primary schools, and the differences in other variables declined in magnitude or statistical significance. Treatment appears to have helped the Onchocerciasis zone became more similar to the rest of the country, but that comparison is merely indicative and the 2006 differences are not reported here; to control for village fixed effects and include data from 1985 and 1996, we now turn to our regression results.

The hypothesis tests and parameter estimates presented below involve various kinds of property rights over cropland, pasture and forest resources. Property rights are a particularly important aspect of institutional development for which no missing values were recorded, so our sample consists of all 615 villages. Our data on public services and infrastructure are analyzed in more detail elsewhere (McMillan, Masters and Kazianga 2011) and have varying sample sizes, limited by whether village leaders could agree on each item's distance from the village. The distances known by almost all of our respondents were to the nearest primary school, health clinic and public market (sample sizes of 609, 602 and 601 villages respectively). At the other extreme, the smallest sample (only 290 villages) could agree on distance to the nearest irrigation dam. This pattern of response is consistent with a valid survey instrument, as there are relatively few irrigation dams in Burkina Faso and for most villages the question would have little salience to peoples' lives.

\section{Identification Strategy}

Our central hypothesis is that villages that had suffered endemic Onchocerciasis were initially smaller than other villages, and saw increased village population in response to OCP treatment. We hypothesize that this treatment exposure was then associated with institutional responses leading to more market-oriented property rights over land use, perhaps in response to increases in productivity, population or both. These hypotheses concern a nationally representative sample of all villages observed today, which combines changes in pre-existing villages with the characteristics of new villages formed after the OCP.

To identify a potentially causal effect of OCP treatment, we use a difference-indifference approach to focus on changes over time in treated as opposed to non-treated areas. Figure 2 illustrates the approach, using village fixed efforts to compare rates of change in a 
nationally-representative sample of villages across the shaded as opposed to non-shared regions. Our sample excludes villages in AVV areas (shown as triangles in Figure 2) since their property rights were centrally planned and not the result of local choices. Our sample includes new villages formed after 1975, perhaps in response to OCP treatment, with robustness tests (not shown in this paper) for internal validity among the villages observed in all four national censuses.

The shaded area in Figure 2 corresponds to the part of the country affected by Onchocerciasis before the OCP began. The burden of disease was unchecked at the time of our first census in 1975, new infections had been halted by the second one in 1985, and symptoms were fully controlled by the third and fourth censuses in 1996 and 2006. Given concerns about serial correlation when difference-in-difference models extend over several years (Bertrand, Duflo and Mullainathan 2004), our preferred specification is to divide the sample into pre- and post-treatment periods (1975 versus 1985-2006). We also show estimation results where the baseline is defined as the period 1975-1985 and the post treatment period as 1996-2006, i.e. when symptoms have been fully controlled. To allow for changes in impact of treatment over time, we show estimation results that use each year's data (with 1975 as baseline), although as shown by Bertrand, Duflo and Mullainathan (2004), the standard errors of these estimates are plausibly under-estimated leading to an over-rejection of the null hypothesis that OCP rollout did not have any impact. Finally, we provide a set of robustness tests for violations of the common trend assumption underlying our difference-in-difference approach.

Disease control could influence institutional development via either the productivity of investments in labor, land and capital, or via the size and density of population as suggested by Boserup (1965). These pathways run together, and may be indistinguishable. Our strategy is to explore them separately, by regressing village population size and institutional choices on treatment status using difference-in-difference specifications. We also test the Boserup hypothesis alone, imposing the assumption that disease burdens influence property rights only through population density.

We estimate the direct effects of OCP on village population and on public institutions in regressions (1) and (2). For population, we estimate:

$$
\text { Pop }_{j t}=\alpha_{1}+\beta_{11}\left(\text { Treat }_{j} \times \text { Time }_{t}\right)+\beta_{12}\left(\text { Time }_{t}\right)+\gamma_{1 j}+\varepsilon_{1 j t}
$$


where $\beta_{11}$ is an estimate of the average effect of treatment on village population $\left(\operatorname{Pop}_{j t}\right)$, across villages and time periods indexed by $j$ and $t$, controlling for a common time effect $\beta_{12}$ and village fixed effects $\gamma_{1 j}$.

For the actions of local institutions, we estimate:

$$
I_{k j t}=\alpha_{2 k}+\beta_{21 k}\left(\text { Treat }_{j} \times \text { Time }_{t}\right)+\beta_{22 k}\left(\text { Time }_{t}\right)+\gamma_{2 k j}+\varepsilon_{2 k j t}
$$

where $\beta_{21 \mathrm{k}}$ estimates the average treatment effect on local institutions' choices $\left(I_{k j t}\right)$ for the $k$ th outcome, across villages and time periods indexed by $j$ and $t$, controlling for a common time effect $\beta_{22 k}$ and village fixed effects $\gamma_{2 k j}$.

We also consider the pure Boserup hypothesis with a regression of institutional choices on population size. The stripped down version of that hypothesis is that local institutions, including amenities and land rights react to changes in population density, in a relationship of the form:

$$
I_{k j t}=\alpha_{3 k}+\beta_{31 k}\left(\text { Pop }_{j t}\right)+\beta_{32 k}\left(\text { Time }_{t}\right)+\gamma_{3 k j}+\varepsilon_{3 k j t}
$$

Here, $\beta_{31 k}$ is the coefficient of interest, but population is endogenous to institutional choices. An OLS estimate of regression (3) would be subject to reverse causality bias, as people may join villages in part because of the land rights available there, and also omitted variable bias, as unobserved factors such as village leadership quality could influence both institutional choices and migration to or from the village. To test the Boserup effect we would need a quasiexperimental, exogenous source of variance in village population. Here we illustrate such a test using the difference-in-difference results of equation (1) as a first stage in 2SLS estimation of equation (3). This estimate of population's effect on institutional choices would be unbiased if OCP treatment impacted institutional choices only through changing village population size, and not through other channels. That exclusion restriction is untestable, so we treat equation (3) as illustrative and focus the analysis on equations (1) and (2), using a difference-in-difference approach to identify the degree to which disease control changed rural demography and local institutional development. 


\section{Results and Discussion}

The results of equation (1) are reported in Table 3, with separate columns for the three different time-period comparisons. The first column compares the baseline (1975) to pooled observations after treatment began (1985, 1996 and 2006). The second compares the period before and during initial adjustment (1975 and 1985) to the post-treatment period (1996 and 2006). Finally, we also compare the baseline to each subsequent year separately. In all three time-period comparisons, village populations increase significantly faster in the treatment areas. Population is expressed in log form, so the coefficients are semi-elasticities. The standard errors in these regressions and in all subsequent tables are clustered at the village level, and each regression controls for 615 village fixed effects, with an average of 3.75 observations per village for a total of 2,307 observations. From column 1, village populations were 33 percent larger in OCP areas after treatment began, comparing 1975 to the three later censuses in 1985, 1996 and 2006. Some but not all of that adjustment occurred in the first decade after treatment began. From column 2, populations were 25 percent larger when comparing 1975-1985 to 1996-2006. The year-by-year estimates in column 3 show treatment raising village population in OCP as opposed to other areas to 24 percent above baseline levels in 1985, and then 39 percent above that baseline in 1996 and 2006. In all three columns the difference-in-difference point estimates are significant at the one percent level, although the standard errors in column (3) may be underestimated as we discussed above.

Results of equations (2) and (3) are reported in Tables 4, 5 and 6. In each of these tables, the three different time-period comparisons are shown, first Panel A where the difference-indifference estimate compares 1975 to the entire 1985-2006 period, then Panel B compares 197586 to 1996-2006, and finally Panel C provides the naïve regression with three year-to-year changes that might be subject to serial correlation. Table 4 reports results for equation (2), showing that land transactions are about 4 percent more likely to be observed after treatment in the OCP area, and also about 4 percent less likely to require a permit. There is also some evidence of increases in whether land rights are assigned to individuals and whether pasture and forest access is regulated, but only after 1985 (Panel B, in the comparison between 1975-85 and 1996-2006). The contrast between the panels provide some suggestive evidence about how institutional adjustment took place over time after treatment began, as cropland transactions 
(Column 2) were significantly more common in treated areas immediately after the OCP began operations in 1975 (Panel A), whereas cropland rights (Column 1) were more often assigned to individuals only after 1985 (Panel B), especially after 1996 (Panel C). Similarly slow adjustment appears for other land tenure dimensions shown in columns 2-5, although less marked.

Tables 5 and 6 report results of equation (3), showing first the OLS estimates linking changes in village population to changes in property rights, and then 2SLS estimates attempting to correct for endogeneity of population change. The OLS estimates in Table 5 rely only on the village fixed effects for identification, while the 2SLS estimates in Table 6 also impose the untestable exclusion restriction that OCP treatment affects institutional choices only through population. Table 5 reveals a robust link to property rights from village population only for the probability of land transactions, with an estimated semi-elasticity of 0.02 across all three time period differences. Table 6 suggests a higher semi-elasticity for land transactions and also significant effects for some other land rights. The first stage for these regressions is Table 3, with the interaction terms as excluded instruments. In each column of Table 3 we show report the Ftest of the null hypothesis that the excluded instruments are jointly insignificant. The null hypothesis can be rejected at the one-percent level for all cases. Moreover, the F-statistics meet the rule of thumb cut-off suggested by Stock and Yogo (2005) in columns 1 and 2, which is an indication of the explanatory power of our instruments. Their validity is untestable, so we conclude only that our difference-in-difference results for land transactions are robust across both the OLS and 2SLS specifications.

\section{Robustness Checks}

In this section we demonstrate that our main results reported in Tables 3 and 4 are robust to several threats to identification, notably the possibility of time-variant heterogeneity which would violate the parallel trends assumption behind our difference-in-difference approach. The treated and control areas are quite far from each other (see Figure 2), and could have experienced systematically different changes in population density and property rights for reasons other than the variables included in our main specifications. Here we test the robustness of our results in two different ways: first we introduce region-year fixed effects to absorb many kinds of 
heterogeneity among Burkina Faso's 13 administrative regions, and then we introduce splitsample tests to address differences based on distance to the rivers where disease vectors breed.

Results using the country's administrative regions are shown in Tables 7 and 8 , addressing the robustness of our main results for population (equation 1, shown in Table 3) and property rights (equation 2, shown in Table 4). In the context of Burkina Faso, administrative regions are small enough to differ from each other in many dimensions, but large enough for each region to include multiple treated and control villages. The use of region-year fixed effects allows us to compare treated villages in OCP areas with untreated villages nearby, thus absorbing a wide range of local trends in unobservable variables that might have influenced each region's change in its population and property rights. These additional controls produce results in Table 7 that are similar to our preferred specification in Table 3, with slightly smaller point estimates and slightly larger standard errors, but all results remain significant.

Table 8 provides only treatment estimates and standard errors to save space, with full regression results available upon request. Here, the point estimates for whether land transactions occurred and whether land rights were assigned to individuals are actually larger than in Table 4, and results remain significant further reinforcing our main result. Estimated standard errors are somewhat larger, but again our results are robust to time varying heterogeneity across the country's diverse administrative regions.

A different kind of robustness check is offered by the split-sample test in Tables 9 and 10. Here our concern is that distance to rivers influenced changes in population and property rights, either independently of Onchocerciasis control or in interaction with it. For example, the value of living close to rivers may change over time for reasons such as access to irrigation or exposure to malaria, and the impact of the OCP itself may have been influenced by proximity to the rivers where blackflies breed. Maps of Onchocerciasis prevalence provide no clear relation between infection and distance to river (de Sole et al. 1991), perhaps because black flies can travel great distances in search of the blood meals that transmit infection (e.g. Cheke and Garms 2013, Johnson et al. 1985). To avoid imposing any particular functional form on a possible distance effect, we divide the sample into halves, separating those closest and furthest from rivers. 
Table 9 investigates the robustness of our results for population (equation 1, shown in Table 3), splitting each regression into the sub-samples of villages nearer or farther from a river in columns a and $\mathrm{b}$ respectively. These results reveal that treatment effects on population are similar in both sub-samples, with coefficient estimates around those of the pooled sample. Standard errors are larger but results remain significant despite the smaller sample sizes.

Table 10 tests the robustness of our results for property rights (equation 2, shown in Table 4), again presenting only the effect estimates and standard errors to save space. The main result regarding land transactions (column 2) is significant in both subsamples, with coefficient estimates around those of the pooled sample that are slightly higher for the villages closer to rivers. Effects of treatment on the assignment of land rights to individuals and the regulation of forest access were significant only in the half of villages closer to rivers, and effects on whether land transactions require a permit were significant only in the half of villages farther from rivers.

The results shown in Tables 3 and 4 are robust to a number of other tests and controls whose results are available on request. First, we controlled for spatially correlated errors using the approach of Conley (1999). In all of these regressions, coefficient estimates and standard errors were very similar to those of Tables 3 and 4 . We also ran all regressions with controls for the dependent variable interacted with time, which affected results only for columns (1) and (3) of Table 3. Then, we considered various sources of heterogeneity in treatment effects, starting with the characteristics of "new villages" observed in 2006 that were not found in the 1975 national census documents. These might be new settlements formed in response to treatment, but could also be villages that are newly formed or more recently identified for other reasons. On average, we found that these new villages were not more likely to be located in the treatment area or near a river, suggesting that other factors dominate the reverse attrition found in our data. Indeed it is possible that many of the new villages actually existed in 1975, but their populations might have been recorded in the census under a different name or as part of a neighboring settlement. To test the influence of newly-identified villages, we excluded them and found very similar results using the smaller balanced sample of villages observed in all four censuses.

To examine other kinds of heterogeneity in treatment effects, we tested two other ways of splitting the sample. One was to address possible differences associated with distance to the nearest AVV planned settlement, and the other was to consider differences based on distance to 
the nearest major city (either Ouagadougou or Bobo Dioulasso). It turns out that treatment effects on population and land transactions are larger and more significant for the half of the sample that is farther from AVV settlements. Villages closer to the AVV areas showed larger treatment effects for only two of the results, land rights for individuals and regulation of forest access. Villages closer to or farther from a city had similar point estimates and standard errors for treatment effects on population and land transactions. The only differences from our main results are that the estimated treatment effect on regulation of access to pasture and forests is significant only in the half of villages closer to a city, while the treatment effect on whether land transactions require a permit is significant only in the half of villages farther from a city. These results parallel the findings of Tables 9 and 10, splitting the sample with respect to distance from a river.

In summary, we find that the main difference-in-difference results in Tables 3 and 4 are largely unchanged through a variety of robustness tests. The most important of these are the controls for the region-year fixed effects shown in Tables 7 and 8, and splitting the sample by distance to river in Tables 9 and 10. Various other controls and tests for heterogeneity strengthen our main result that OCP treatment led to larger populations and greater likelihood of land transactions, as well as less likelihood that land transactions require a permit, greater assignment of land rights to individuals, and more regulation of access to common pasture and forest lands.

\section{Conclusion}

This paper uses variance in population size, land use rights and distance to specific amenities in a nationally representative sample of 615 villages to examine how rural demography and property rights over agricultural land responded to Onchocerciasis disease control in Burkina Faso between 1975 and 2006. Our central hypothesis is that river blindness control led to larger village populations in treated areas, with more market-oriented governance of land use. Our data on rural demography come from four national censuses, in 1975 (just before the blackfly vector transmitting the disease was targeted by the Onchocerciasis Control Program), 1985 (just before the OCP distributed ivermectin to block symptoms among those already infected), 1996 (after vector control ceased and new symptoms were no longer widely felt), and 2006 (after the OCP ended). Each village's exposure to Onchocerciasis is captured by its presence in the treated 
zone, and our data on rural institutions' response come from a new survey of village elders designed to document change over time in their land-use rights and distance to frequently used amenities.

Results show strong links between disease control, rural demography and institutional response. Before treatment began in 1975, villages in the Onchocerciasis zone had significantly smaller populations than villages elsewhere. Treated villages then expanded by 25-33 percent depending on the time period specified, cutting the difference in average village size to statistical insignificance in 2006. Similarly, in 1975 villages in the Onchocerciasis zone were significantly less likely than others to assign cropland property rights to individuals, and more likely to require permits for land transactions. After treatment, those villages were significantly more likely to have land transactions, and less likely to require permits before those transactions. They also came to be more closely served by rural amenities, especially public markets and also primary schooling and telephone service. These differences could have occurred through the Boserup effect of treatment on population size, or could have occurred more directly through shifts in village productivity.

An important feature of our study is its use of village elders' recall data to construct timevarying measures of the actions taken by local public institutions. This involves asking about villagers' use of specific agricultural property rights and their distance access to specific public services. The resulting data offer rich detail how well each village is served by local public institutions, demonstrating the potential of this approach to help overcome the limited availability of reliable evidence from other sources on variation in land use rights, public services or other choices made by local institutions.

In the particular setting of rural Burkina Faso, we find that a major regional disease control effort led to significant changes in village sizes, more market-oriented land use rights, and closer provision of some public amenities. Such demographic and institutional changes are clearly of great importance for Africa and other regions where endemic diseases are rooted in particular locations. Future work using similar data sources could document further how public health interventions change the rural landscape and the prospects for economic development. 


\section{References Cited}

Acemoglu, Daron and Simon Johnson, 2007. "Disease and Development: The Effect of Life Expectancy on Economic Growth." Journal of Political Economy, 115(6): 925-985.

Ashraf, Quamrul H., Ashley Lester and David N. Weil, 2009. "When Does Improving Health Raise GDP?" in NBER Macroeconomics Annual 2008, Volume 23: 157-204.

Benton, Bruce, Jesse Bump, A.V. Sékétéli, and B.H. Liese. 2002. "Partnership and Promise: Evolution of the African River-blindness Campaigns." Annals of Tropical Medicine and Parasitology 96(1): 5-14.

Bertrand, Marianne, Esther Duflo and Sendhil Mullainathan, 2004. "How Much Should We Trust Differences-in-Differences Estimates?" Quarterly Journal of Economics, 119(1): 249-275.

Besley, Timothy, 1995. "Property Rights and Investment Incentives: Theory and Evidence from Ghana." The Journal of Political Economy, 103(5): 903-937.

Bleakley, Hoyt. 2007. "Disease and Development: Evidence from Hookworm Eradication in the American South." The Quarterly Journal of Economics, 122(1): 73-117.

Bloom, David E. and Jeffrey G. Williamson, 1998. "Demographic Transitions and Economic Miracles in Emerging Asia.” World Bank Economic Review 12(3): 419-455.

Boserup, Ester, 1965. The Conditions of Agricultural Growth: The Economics of Agrarian Change under Population Pressure. London, G. Allen and Unwin, 1965.

Chambers, Robert, 1994. "The origins and practice of participatory rural appraisal." World Development, 22(7): 953-969.

Chattopadhyay, Raghabendra and Esther Duflo, 2004. "Women as Policy Makers: Evidence from a Randomized Policy Experiment in India," Econometrica, 72(5): 1409-1443.

Cheke, Robert A. and Rolf Garms, 2013. "Indices of onchocerciasis transmission by different members of the Simulium damnosum complex conflict with the paradigm of forest and savanna parasite strains." Acta Tropica, 125(1): 43-52.

Conley, Timothy G. 1999. "GMM Estimation with Cross Sectional Dependence.” Journal of Econometrics 92 (1): 1-45. 
Cutler, David, Winnie Fung, Michael Kremer, Monica Singhal, and Tom Vogl. 2010. "EarlyLife Malaria Exposure and Adult Outcomes: Evidence from Malaria Eradication in India." American Economic Journal: Applied Economics, 2(2): 72-94.

de Sole, G, J. Giese, F. M. Keita and J. Remme, 1991 "Detailed epidemiological mapping of three onchocerciasis foci in West Africa," Acta Tropica 48(3): 203-213

Galor, Oded and David N. Weil, 1999. "From Malthusian Stagnation to Modern Growth," American Economic Review, 89(2): 150-154.

Galor, Oded, 2012. "The Demographic Transition: Causes and Consequences,"Cliometrica, 6(1): $1-28$.

Grimm, Michael and Klasen, Stephan, 2008. "Geography vs. Institutions at the Village Level". IZA Discussion Paper No. 3391. Bonn: IZA, 29 pages.

Hayami, Yuhiro and Vernon W. Ruttan, 1971. Agricultural Development: An International Perspective. Baltimore, MD: Johns Hopkins University Press.

Imbens, Guido and Joshua Angrist. 1994. "Identification and Estimation of Local Average Treatment Effects." Econometrica, 62(2): 467-475.

Jedwab, Remi and Alexander Moradi, 2011. "Transportation Infrastructure and Development in Ghana.” Paris School of Economics Working Paper No. 2011-24. Paris: PSE, 47 pages.

Johnson, C. G., J. F. Walsh, J. B. Davies, S. J. Clark and J. N. Perry. 1985. "The pattern and speed of displacement of females of Simulium damnosum Theobald s.l. (Diptera: Simuliidae) across the Onchocerciasis Control Programme area of West Africa in 1977 and 1978." Bulletin of Entomological Research, 75, pp 73-92.

Johnston, Bruce and Peter Kilby, 1975. Agriculture and Structural Transformation. New York: Oxford University Press.

Kazianga, Harounan and William A. Masters, 2002. "Investing in soils: field bunds and microcatchments in Burkina Faso." Environment and Development Economics, 7: 571591

Kazianga, Harounan and William A. Masters, 2006. "Property rights, production technology, and deforestation: cocoa in Cameroon." Agricultural Economics 35 (1): 19-26.

Levine, Ruth, 2004. Case Studies in Global Health: Millions Saved. Case 7: Controlling Onchocerciasis in Sub-Saharan Africa. London: Jones \& Bartlett Publishers. 
Lin, Justin Yifu, 1995. "Endowments, Technology, and Factor Markets: A Natural Experiment of Induced Institutional Innovation from China's Rural Reform." American Journal of Agricultural Economics 77(2): 231-242.

Masters, William A. and Margaret S. McMillan, 2001. "Climate and Scale in Economic Growth," Journal of Economic Growth, 6(3): 167-186.

McMillan, Della E., Jean-Baptiste Nana and Kimseyinga Savadogo, 1992. “Adaptation of RAP to Monitoring Settlement Trends in Areas Covered by Successful Disease Control Programmes: Onchocerciasis", in N.S. Scrimshaw and G.R. Gleason, eds. Rapid Assessment Procedures: Qualitative Methodologies for Planning and Evaluation of Health Related Programmes. Boston, MA: International Nutrition Foundation.

McMillan, Della E., Jean-Baptiste Nana and Kimseyinga Savadogo, 1993. "Settlement and Development in the River Blindness Control Zone." World Bank Technical Paper No. 200, Series on River Blindness Control in West Africa. Washington, DC: World Bank.

McMillan, Margaret, 2001. "Why Kill the Golden Goose? A Political-Economy Model of Export Taxation." Review of Economics and Statistics, 83 (1): 170-184.

McMillan, Margaret and William A. Masters, 2003. "An African Growth Trap." Review of Development Economics 7(2): 179-191.

McMillan, Margaret, William A. Masters and Harounan Kazianga, 2011. "Rural Demography, Public Services and Land Rights in Africa: A Village-Level Analysis in Burkina Faso". NBER Working Paper No. 17718 (December). Cambridge, MA: NBER.

Olmstead, Alan L. and Paul Rhode, 1993. "Induced Innovation in American Agiculture: A Reconsideration." Journal of Political Economy, 101 (1): 100-118.

Pande, Rohini and Chris Udry, 2006. "Institutions and Development: A View from Below," in Proceedings of the 9th World Congress of the Econometric Society, edited by R. Blundell, W.Newey and T.Persson, Cambridge University Press.

Stock, J.H. and M. Yogo (2005). "Testing for Weak Instruments in Linear IV Regression", Chapter 5 (pages 80-108) in D.W.K. Andrews and J.H Stock, eds., Identification and Inference for Econometric Models, Cambridge University Press.

Temple, Jonathan R. W. (2005). "Dual economy models." The Manchester School, 73(4), 435478. 
Figure 1. Estimated Onchocerciasis Prevalence in West Africa

Panel (a): Prior to control (1974)

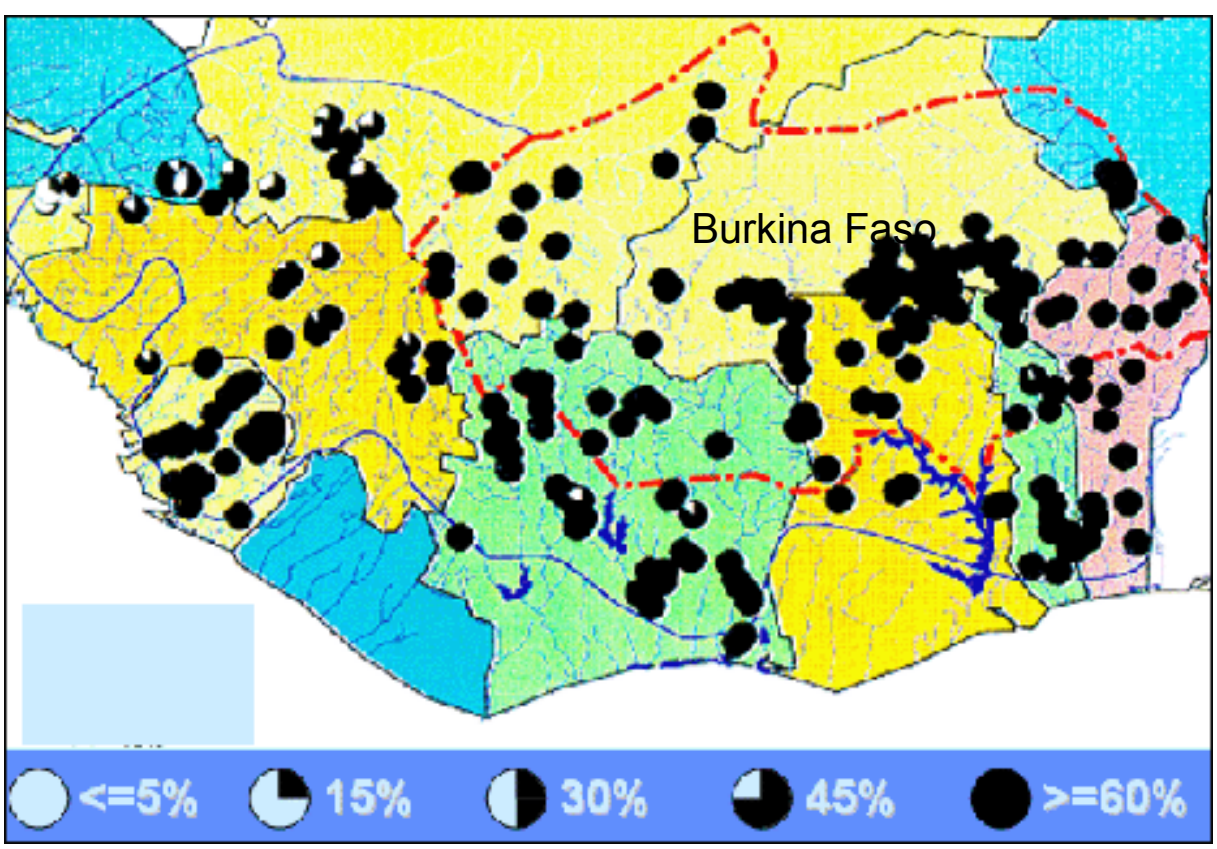

Panel (b): After control (2002)

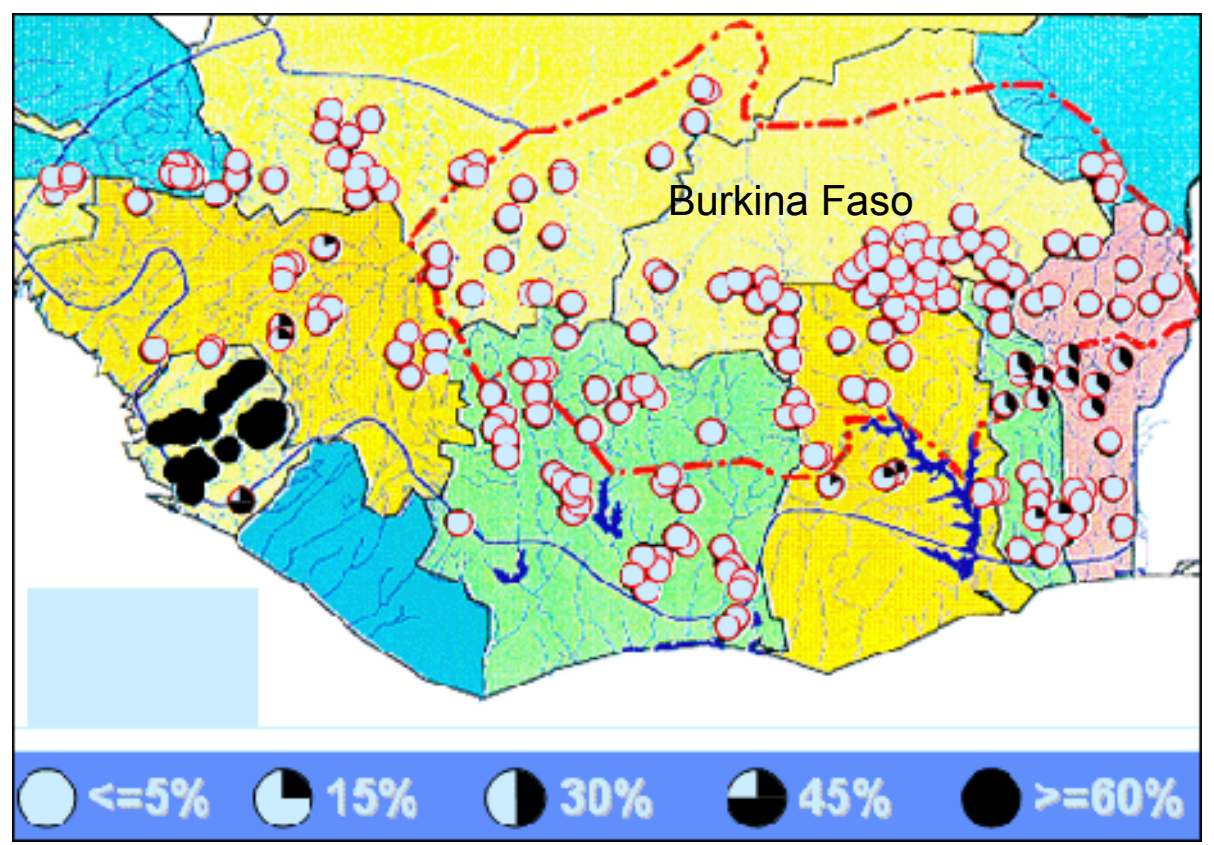

Source: WHO, Onchocerciasis Control Programme (www.who.int/apoc/onchocerciasis/ocp). 
Figure 2. Village Location, Population Growth from 1975 to 1985 and Onchocersiasis Treatment Areas in Burkina Faso

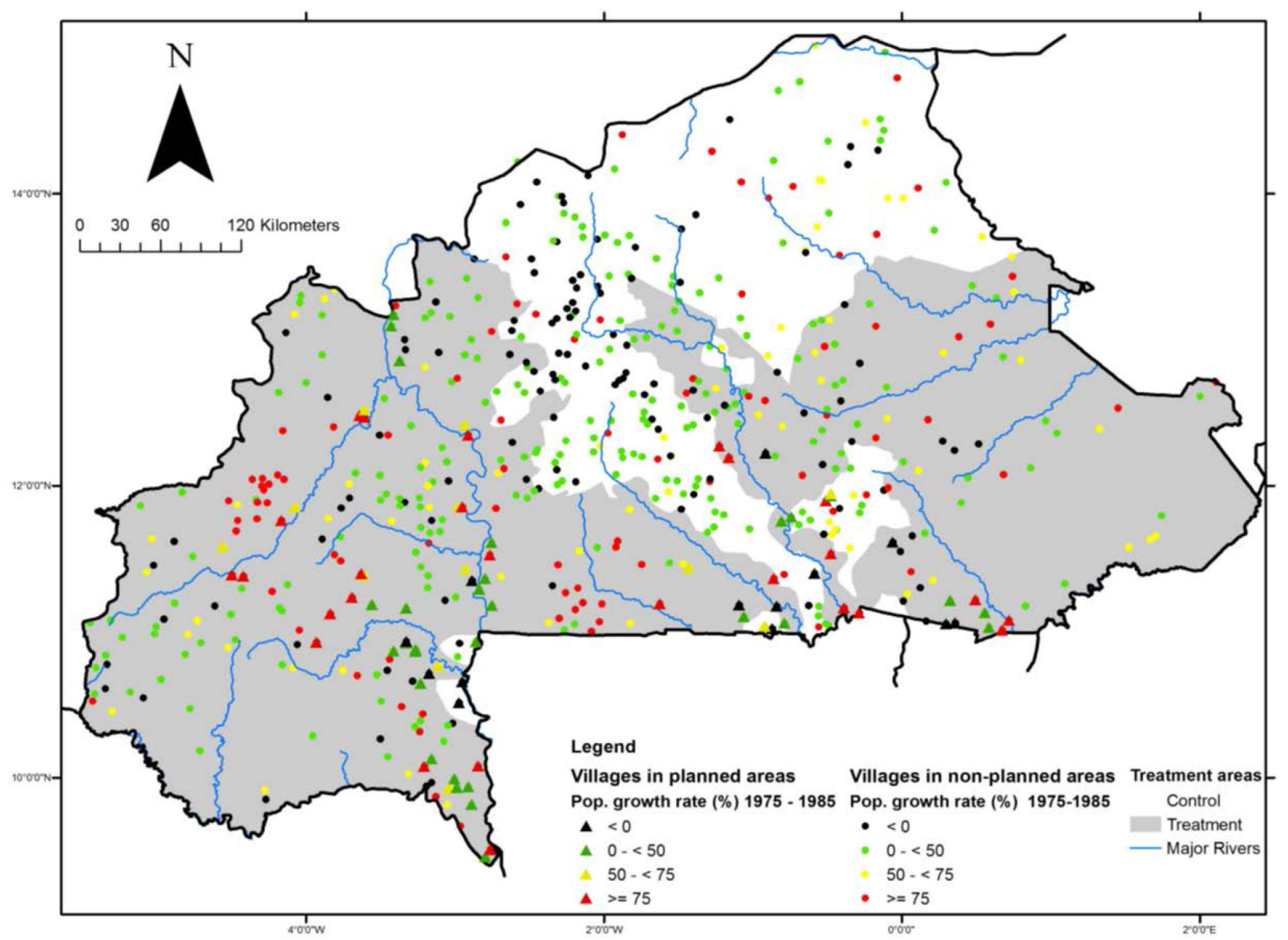

Source: Authors' calculations. Population growth is from Burkina Faso census data of 1975 and 1985. Areas of Onchocerciasis treatment and village planning are from OCP file data, courtesy of Bruce Benton. Location of rivers is from IFPRI mapping file data; location of surveyed villages is from authors' survey data. 
Table 1: Mean, standard deviation, and sample size for all variables in each year

Panel A: Village population and indicators of agricultural land-use rights

\begin{tabular}{lcccccc}
\hline & $\begin{array}{c}\text { Village } \\
\text { population } \\
\text { (from census) }\end{array}$ & $\begin{array}{c}\text { Land rights } \\
\text { assigned to } \\
\text { individuals }\end{array}$ & $\begin{array}{c}\text { Land } \\
\text { transactions } \\
\text { occurred }\end{array}$ & $\begin{array}{c}\text { Pasture } \\
\text { access is } \\
\text { regulated }\end{array}$ & $\begin{array}{c}\text { Forest } \\
\text { access is } \\
\text { regulated }\end{array}$ & $\begin{array}{c}\text { Land } \\
\text { transactions } \\
\text { require permit }\end{array}$ \\
\hline Year = 1975 & 1,266 & 0.378 & 0.846 & 0.228 & 0.075 & 0.335 \\
Year = 1985 & $(1,248)$ & $(0.485)$ & $(0.361)$ & $(0.420)$ & $(0.263)$ & $(0.473)$ \\
& 1,637 & 0.400 & 0.862 & 0.293 & 0.096 & 0.348 \\
Year = 1996 & $(1,561)$ & $(0.490)$ & $(0.346)$ & $(0.456)$ & $(0.294)$ & $(0.477)$ \\
& 1,659 & 0.409 & 0.868 & 0.350 & 0.135 & 0.352 \\
Year = 2006 & $(1,413)$ & $(0.492)$ & $(0.339)$ & $(0.477)$ & $(0.342)$ & $(0.478)$ \\
& 1,414 & 0.435 & 0.889 & 0.425 & 0.173 & 0.371 \\
Observations & $(2,597)$ & $(0.496)$ & $(0.314)$ & $(0.495)$ & $(0.378)$ & $(0.484)$ \\
Villages & 2,307 & 2,307 & 2,307 & 2,307 & 2,307 & 2,307 \\
& 615 & 615 & 615 & 615 & 615 & 615 \\
\hline
\end{tabular}

Panel B: Distance from village to nearest public amenity $(\mathrm{km})$

\begin{tabular}{|c|c|c|c|c|c|c|c|c|}
\hline & \multicolumn{2}{|c|}{ Transport } & \multicolumn{3}{|c|}{ Services } & \multicolumn{3}{|c|}{ Markets } \\
\hline & Road & Bus Stop & Bank & Electricity & Telephone & Public & Livestock & Private \\
\hline \multirow[t]{2}{*}{ Year $=1975$} & 3.79 & 17.60 & 49.03 & 57.17 & 40.84 & 7.85 & 20.67 & 5.63 \\
\hline & (7.21) & $(22.86)$ & (47.49) & (43.69) & $(35.48)$ & $(16.80)$ & $(30.26)$ & (10.08) \\
\hline \multirow[t]{2}{*}{ Year $=1985$} & 4.34 & 13.93 & 39.29 & 51.12 & 37.11 & 5.73 & 22.46 & 5.18 \\
\hline & (13.92) & (18.55) & (35.52) & $(36.07)$ & (31.71) & (8.10) & $(29.82)$ & $(8.90)$ \\
\hline \multirow[t]{2}{*}{ Year $=1996$} & 4.91 & 12.99 & 35.12 & 46.91 & 28.28 & 5.28 & 20.55 & 4.68 \\
\hline & (14.21) & (17.43) & (30.91) & $(33.86)$ & (24.64) & (8.12) & $(26.01)$ & $(9.02)$ \\
\hline \multirow[t]{2}{*}{ Year $=2006$} & 4.32 & 10.64 & 25.81 & 36.73 & 21.34 & 4.85 & 17.07 & 2.09 \\
\hline & (13.44) & (15.82) & (24.21) & (26.39) & (19.67) & (7.52) & (20.57) & $(5.25)$ \\
\hline Observations & 1,433 & 1,719 & 1,084 & 1,227 & 1,589 & 2,216 & 1,042 & 1,228 \\
\hline Villages & 449 & 518 & 559 & 462 & 557 & 601 & 339 & 549 \\
\hline
\end{tabular}

\begin{tabular}{|c|c|c|c|c|c|c|c|c|c|}
\hline & \multicolumn{3}{|c|}{ Water } & \multicolumn{3}{|c|}{ Schooling and Health } & \multicolumn{3}{|c|}{ Religious Services } \\
\hline & Well & Borehole & Dam & Primary & Secondary & Clinic & Church & Mosque & Temple \\
\hline \multirow[t]{2}{*}{ Year $=1975$} & 1.11 & 1.52 & 18.59 & 10.73 & 51.74 & 16.30 & 8.95 & 5.46 & 9.48 \\
\hline & (4.69) & (4.95) & $(21.76)$ & $(12.84)$ & $(39.86)$ & (17.33) & (13.55) & $(11.40)$ & (12.14) \\
\hline \multirow[t]{2}{*}{ Year $=1985$} & 0.74 & 0.63 & 18.12 & 6.94 & 40.14 & 12.70 & 4.88 & 3.92 & 5.09 \\
\hline & (3.42) & $(2.90)$ & $(20.10)$ & (11.74) & $(33.60)$ & (13. & $(9.73)$ & (7.30) & (8.85) \\
\hline \multirow[t]{2}{*}{ Year $=1996$} & 0.89 & 0.57 & 16 & 3.73 & 26.07 & 8.79 & 4.97 & 3.88 & 5.09 \\
\hline & (3.33) & $(2.69)$ & (19.02) & $(8.46)$ & $(24.02)$ & (10.56) & $(9.84)$ & (7.29) & (8.95) \\
\hline \multirow[t]{2}{*}{ Year $=2006$} & 0.30 & 0.33 & 15.41 & 1.14 & 17.32 & 5.91 & 3.55 & 2.63 & 3.01 \\
\hline & $(1.30)$ & $(2.07)$ & $(18.15)$ & $(4.43)$ & $(16.66)$ & $(6.76)$ & $(8.65)$ & (5.73) & $(6.42)$ \\
\hline Observations & 1,041 & 1,062 & 753 & 2,025 & 1,681 & 2,055 & 1,694 & 1,777 & 1,410 \\
\hline Villages & 322 & 414 & 249 & 573 & 528 & 574 & 471 & 505 & 411 \\
\hline
\end{tabular}

Notes: All data are from authors' survey of village elders in 2010, except village population which is from Burkina Faso national censuses. The sample size of villages shown is the number included in the 2006 census, not all of which have populations recorded in previous censuses, leading to the number of observations shown. Indicators in Panel A are 1 if the condition shown is met, and zero otherwise, with no missing values recorded. Distances in Panel B have missing values where no answer was recorded. The specific wording of each question is reproduced in the online appendix. These summary statistics are for our preferred sample, excluding villages in AVV planning areas. 
Table 2: Mean, standard deviation and difference between treated and control areas in the baseline year (1975)

\begin{tabular}{|c|c|c|c|c|c|c|c|}
\hline & Treated & Control & Difference & & Treated & Control & Difference \\
\hline \multirow[t]{2}{*}{ Village population } & $\begin{array}{l}1130.703 \\
{[70.242]}\end{array}$ & $\begin{array}{l}1468.08 \\
{[90.799]}\end{array}$ & $\begin{array}{l}-337.378^{* \star \star} \\
{[114.797]}\end{array}$ & \multicolumn{4}{|c|}{$\begin{array}{l}\text { Continued from previous column } \\
\text { Distance from village to nearest public amenity (km) }\end{array}$} \\
\hline & & & & Public Market & 9.092 & 5.934 & $3.158^{* *}$ \\
\hline \multicolumn{4}{|c|}{ Indicators of agricultural land-use rights } & & [1.194] & [0.713] & {$[1.390]$} \\
\hline \multirow[t]{2}{*}{ Land rights assigned to individuals } & 0.328 & 0.452 & $-0.125^{* * *}$ & Livestock Market & 25.140 & 15.013 & $10.127^{* *}$ \\
\hline & {$[0.027]$} & [0.035] & {$[0.045]$} & & [3.584] & [2.253] & [4.233] \\
\hline \multirow[t]{2}{*}{ Land transactions occurred } & 0.834 & 0.864 & -0.030 & Private Shop & 6.231 & 4.750 & 1.481 \\
\hline & [0.022] & [0.024] & [0.033] & & {$[1.470]$} & {$[1.011]$} & {$[1.784]$} \\
\hline \multirow[t]{2}{*}{ Pasture access is regulated } & 0.206 & 0.261 & -0.055 & Water Well & 1.658 & 0.429 & $1.230^{*}$ \\
\hline & [0.024] & [0.031] & [0.039] & & [0.694] & {$[0.143]$} & [0.709] \\
\hline \multirow[t]{2}{*}{ Forest access is regulated } & 0.084 & 0.06 & 0.024 & Borehole & 0.833 & 2.154 & -1.321 \\
\hline & {$[0.016]$} & {$[0.017]$} & {$[0.023]$} & & [0.833] & [1.764] & [1.951] \\
\hline \multirow[t]{3}{*}{ Land transactions require permit } & 0.389 & 0.256 & $0.132^{* * *}$ & Dam & 24.96 & 8.625 & $16.335^{* * *}$ \\
\hline & [0.028] & [0.031] & {$[0.042]$} & & [3.490] & [1.823] & [3.937] \\
\hline & & & & Primary School & 11.818 & 9.068 & $2.750^{\star \star}$ \\
\hline \multicolumn{4}{|c|}{ Distance from village to nearest public amenity $(\mathrm{km})$} & & {$[0.820]$} & [1.112] & {$[1.382]$} \\
\hline \multirow[t]{2}{*}{ Road } & 4.196 & 3.192 & 1.004 & Secondary Sch. & 56.294 & 44.958 & $11.335^{\star * *}$ \\
\hline & {$[0.618]$} & [0.639] & [0.889] & & [3.221] & [4.190] & {$[5.284]$} \\
\hline \multirow[t]{2}{*}{ Bus Stop } & 18.354 & 16.408 & 1.946 & Health Clinic & 16.603 & 15.828 & 0.775 \\
\hline & {$[1.627]$} & [2.160] & [2.704] & & [1.086] & [1.440] & [1.803] \\
\hline \multirow[t]{2}{*}{ Bank } & 66.361 & 31.200 & $35.161^{* * *}$ & Church & 9.692 & 8.000 & 1.692 \\
\hline & [9.633] & [3.998] & {$[10.429]$} & & {$[1.052]$} & [1.146] & {$[1.556]$} \\
\hline \multirow[t]{2}{*}{ Electricity } & 73.061 & 39.800 & $33.261^{* * *}$ & Mosque & 6.236 & 4.200 & $2.036^{*}$ \\
\hline & [4.903] & [4.133] & [6.412] & & {$[1.006]$} & [0.657] & [1.201] \\
\hline \multirow[t]{2}{*}{ Telephone } & 45.46 & 32.862 & $12.598^{\star * *}$ & Temple & 10.189 & 8.580 & 1.610 \\
\hline & [3.165] & [2.934] & [4.316] & & [1.263] & [1.119] & [1.687] \\
\hline
\end{tabular}

Notes: Approximately 60 percent of surveyed villages are in treated areas. Significance levels for t-tests of difference between villages in treated and control areas are shown are $* * * \mathrm{p}<0.01, * * \mathrm{p}<0.05$, and $* \mathrm{p}<0.1$. 
Table 3: OLS results for village population on Onchocerciasis treatment status and time

\begin{tabular}{|c|c|c|c|}
\hline $\begin{array}{l}\text { Dependent variable: } \\
\text { log of village population }\end{array}$ & $\begin{array}{l}\text { Post-75 } \\
\text { (1) }\end{array}$ & $\begin{array}{l}\text { Post-85 } \\
(2)\end{array}$ & $\begin{array}{l}\text { Annual Data } \\
\text { (3) }\end{array}$ \\
\hline Treated X Post-75 (1985-2006) & $\begin{array}{l}0.33^{* * *} \\
(0.08)\end{array}$ & & \\
\hline Treated X Post-85 (1996-2006) & & $\begin{array}{l}0.25^{* * *} \\
(0.07)\end{array}$ & \\
\hline Treated X 1985 & & & $\begin{array}{l}0.24^{* * *} \\
(0.09)\end{array}$ \\
\hline Treated X 1996 & & & $\begin{array}{l}0.39^{* * *} \\
(0.09)\end{array}$ \\
\hline Treated X 2006 & & & $\begin{array}{l}0.39^{* * *} \\
(0.11)\end{array}$ \\
\hline Post-75 (1985-2006) & $\begin{array}{l}0.09 \\
(0.06)\end{array}$ & & \\
\hline Post-85 (1996-2006) & & $\begin{array}{l}-0.09^{*} \\
(0.05)\end{array}$ & \\
\hline Year $=1985$ & & & $\begin{array}{l}0.21^{* * *} \\
(0.06)\end{array}$ \\
\hline Year $=1996$ & & & $\begin{array}{l}0.17^{* *} \\
(0.07)\end{array}$ \\
\hline Year $=2006$ & & & $\begin{array}{l}-0.11 \\
(0.09)\end{array}$ \\
\hline Constant & $\begin{array}{l}6.68^{* \star *} \\
(0.03)\end{array}$ & $\begin{array}{l}6.88^{* * *} \\
(0.02)\end{array}$ & $\begin{array}{l}6.68^{* * *} \\
(0.03)\end{array}$ \\
\hline R-squared & 0.47 & 0.45 & 0.48 \\
\hline $\begin{array}{l}\text { F-Stat Inst. } \\
\text { p value }\end{array}$ & $\begin{array}{l}17.59 \\
0.000\end{array}$ & $\begin{array}{l}12.44 \\
0.000\end{array}$ & $\begin{array}{l}7.137 \\
0.000\end{array}$ \\
\hline
\end{tabular}

Notes: All regressions have 2,307 observations and control for 615 village fixed effects, with standard errors clustered at the village level. Significance levels shown are ${ }^{* *} \mathrm{p}<0.01, * * \mathrm{p}<0.05$, and $* \mathrm{p}<0.1$. F-test and $\mathrm{p}$ values are shown for the treatment variables in this regression, which is used to instrument population as the first stage for the 2SLS regressions in Table 6. 
Table 4: OLS results for property rights on Onchocerciasis treatment status and time

\begin{tabular}{|c|c|c|c|c|c|}
\hline Dependent variable: & $\begin{array}{l}\text { Land } \\
\text { rights assigned } \\
\text { to individuals } \\
\text { (1) }\end{array}$ & $\begin{array}{l}\text { Land } \\
\text { transactions } \\
\text { occurred } \\
(2)\end{array}$ & $\begin{array}{l}\text { Pasture } \\
\text { access is } \\
\text { regulated } \\
(3)\end{array}$ & $\begin{array}{l}\text { Forest } \\
\text { access is } \\
\text { regulated } \\
(4)\end{array}$ & $\begin{array}{l}\text { Land } \\
\text { transactions } \\
\text { require permit } \\
(5)\end{array}$ \\
\hline \multicolumn{6}{|l|}{ Panel A: Post-1975 } \\
\hline \multirow[t]{2}{*}{$\begin{array}{l}\text { Treated X Post-75 } \\
(1985-2006)\end{array}$} & 0.02 & $0.04^{* * *}$ & 0.02 & $0.03^{*}$ & $-0.04^{* * *}$ \\
\hline & $(0.01)$ & $(0.01)$ & $(0.03)$ & $(0.02)$ & $(0.01)$ \\
\hline \multirow[t]{2}{*}{ Time $=1985-2006$} & $0.02^{* *}$ & 0.00 & $0.11^{* * *}$ & $0.04^{\star \star *}$ & $0.04^{* * *}$ \\
\hline & $(0.01)$ & $(0.00)$ & $(0.02)$ & $(0.01)$ & $(0.01)$ \\
\hline \multirow[t]{2}{*}{ Constant } & $0.39^{* * *}$ & $0.84^{* * *}$ & $0.23^{\star \star \star}$ & $0.08^{* * *}$ & $0.34^{* * *}$ \\
\hline & $(0.01)$ & $(0.01)$ & $(0.01)$ & $(0.01)$ & $(0.01)$ \\
\hline R-squared & 0.96 & 0.92 & 0.83 & 0.83 & 0.96 \\
\hline \multicolumn{6}{|l|}{ Panel B: Post-1985 } \\
\hline \multirow{3}{*}{$\begin{array}{l}\text { Treated X Post-85 } \\
(1996-2006)\end{array}$} & & & & & \\
\hline & $0.02^{* *}$ & $0.04^{* * *}$ & $0.05^{* * *}$ & $0.02^{*}$ & $-0.05^{\star * *}$ \\
\hline & $(0.01)$ & $(0.01)$ & $(0.02)$ & $(0.01)$ & $(0.01)$ \\
\hline \multirow[t]{2}{*}{ Time $=1996-2006$} & $0.02^{* * *}$ & $0.00^{*}$ & $0.09^{* * *}$ & $0.05^{* * *}$ & $0.04^{* * *}$ \\
\hline & $(0.01)$ & $(0.00)$ & $(0.01)$ & $(0.01)$ & $(0.01)$ \\
\hline \multirow[t]{2}{*}{ Constant } & $0.39^{* * *}$ & $0.85^{\star * \star}$ & $0.26^{* * *}$ & $0.09^{* * *}$ & $0.34^{* * *}$ \\
\hline & $(0.00)$ & $(0.00)$ & $(0.01)$ & $(0.00)$ & $(0.00)$ \\
\hline$\underline{R}$-squared & 0.96 & 0.93 & 0.84 & 0.84 & 0.96 \\
\hline \multicolumn{6}{|c|}{ Panel C: Annual Data } \\
\hline \multirow[t]{2}{*}{ Treated X 1985} & 0.00 & $0.03^{* *}$ & -0.01 & 0.02 & -0.02 \\
\hline & $(0.01)$ & $(0.01)$ & $(0.03)$ & $(0.02)$ & $(0.02)$ \\
\hline \multirow[t]{2}{*}{ Treated X 1996} & 0.01 & $0.04^{* * *}$ & 0.03 & 0.03 & $-0.05^{\star * *}$ \\
\hline & $(0.01)$ & $(0.01)$ & $(0.03)$ & $(0.02)$ & $(0.02)$ \\
\hline \multirow[t]{2}{*}{ Treated X 2006} & $0.03^{* *}$ & $0.07^{* * *}$ & 0.05 & $0.04^{*}$ & $-0.07^{* * *}$ \\
\hline & $(0.01)$ & $(0.01)$ & $(0.03)$ & $(0.02)$ & $(0.02)$ \\
\hline \multirow[t]{2}{*}{ Year $=1985$} & 0.01 & 0.00 & $0.07^{* * *}$ & 0.00 & 0.02 \\
\hline & $(0.01)$ & $(0.00)$ & $(0.02)$ & $(0.01)$ & $(0.01)$ \\
\hline \multirow[t]{2}{*}{ Year $=1996$} & $0.02^{* *}$ & 0.00 & $0.10^{* * *}$ & $0.04^{* * *}$ & $0.04^{* * *}$ \\
\hline & $(0.01)$ & $(0.00)$ & $(0.02)$ & $(0.01)$ & $(0.01)$ \\
\hline \multirow[t]{2}{*}{ Year $=2006$} & $0.03^{* * *}$ & 0.00 & $0.17^{* * *}$ & $0.07^{* * *}$ & $0.07^{* * *}$ \\
\hline & $(0.01)$ & $(0.00)$ & $(0.02)$ & $(0.01)$ & $(0.01)$ \\
\hline \multirow[t]{2}{*}{ Constant } & $0.39^{\star * *}$ & $0.84^{* * *}$ & $0.23^{* * *}$ & $0.08^{* * *}$ & $0.34^{* * *}$ \\
\hline & $(0.01)$ & $(0.01)$ & $(0.01)$ & $(0.01)$ & $(0.01)$ \\
\hline R-squared & 0.96 & 0.93 & 0.85 & 0.84 & 0.96 \\
\hline
\end{tabular}

Notes: All regressions have 2,307 observations and control for 615 village fixed effects, with standard errors clustered at the village level. Significance levels shown are ${ }^{* *} \mathrm{p}<0.01, * * \mathrm{p}<0.05$, and $* \mathrm{p}<0.1$. 
Table 5: OLS results for property rights on village population and time

\begin{tabular}{|c|c|c|c|c|c|}
\hline Dependent variable: & $\begin{array}{l}\text { Land } \\
\text { rights assigned } \\
\text { to individuals } \\
\text { (1) }\end{array}$ & $\begin{array}{l}\text { Land } \\
\text { transactions } \\
\text { occurred } \\
(2)\end{array}$ & $\begin{array}{l}\text { Pasture } \\
\text { access is } \\
\text { regulated } \\
\text { (3) }\end{array}$ & $\begin{array}{l}\text { Forest } \\
\text { access is } \\
\text { regulated } \\
\text { (4) }\end{array}$ & $\begin{array}{l}\text { Land } \\
\text { transactions } \\
\text { require permit } \\
\text { (5) }\end{array}$ \\
\hline \multicolumn{6}{|l|}{ Panel A: Post-1975 } \\
\hline Population (log) & $\begin{array}{l}-0.00 \\
(0.00)\end{array}$ & $\begin{array}{l}0.02^{* * *} \\
(0.00)\end{array}$ & $\begin{array}{l}-0.01 \\
(0.01)\end{array}$ & $\begin{array}{l}-0.00 \\
(0.01)\end{array}$ & $\begin{array}{l}0.00 \\
(0.00)\end{array}$ \\
\hline Time $=1985-2006$ & $\begin{array}{l}0.03^{\star * *} \\
(0.01)\end{array}$ & $\begin{array}{l}0.03^{\star * *} \\
(0.01)\end{array}$ & $\begin{array}{l}0.13^{\star * \star} \\
(0.01)\end{array}$ & $\begin{array}{l}0.05^{\star * *} \\
(0.01)\end{array}$ & $\begin{array}{l}0.01^{* *} \\
(0.01)\end{array}$ \\
\hline Constant & $\begin{array}{l}0.39^{* * *} \\
(0.02)\end{array}$ & $\begin{array}{l}0.74^{* * *} \\
(0.03)\end{array}$ & $\begin{array}{l}0.29^{* * *} \\
(0.05)\end{array}$ & $\begin{array}{l}0.10^{* *} \\
(0.04)\end{array}$ & $\begin{array}{l}0.34^{* * *} \\
(0.02)\end{array}$ \\
\hline R-squared & 0.96 & 0.93 & 0.83 & 0.83 & 0.95 \\
\hline \multicolumn{6}{|l|}{ Panel B: Post-1985 } \\
\hline Population (log) & $\begin{array}{l}0.00 \\
(0.00)\end{array}$ & $\begin{array}{l}0.02^{* * *} \\
(0.00)\end{array}$ & $\begin{array}{l}-0.00 \\
(0.01)\end{array}$ & $\begin{array}{l}0.00 \\
(0.01)\end{array}$ & $\begin{array}{l}0.00 \\
(0.00)\end{array}$ \\
\hline Time $=1996-2006$ & $\begin{array}{l}0.03^{* * *} \\
(0.00)\end{array}$ & $\begin{array}{l}0.03^{* * *} \\
(0.00)\end{array}$ & $\begin{array}{l}0.12^{* * *} \\
(0.01)\end{array}$ & $\begin{array}{l}0.06^{* * *} \\
(0.01)\end{array}$ & $\begin{array}{l}0.02^{* * *} \\
(0.00)\end{array}$ \\
\hline Constant & $\begin{array}{l}0.38^{* * *} \\
(0.02)\end{array}$ & $\begin{array}{l}0.74^{* * *} \\
(0.03)\end{array}$ & $\begin{array}{l}0.27^{* * *} \\
(0.05)\end{array}$ & $\begin{array}{l}0.09^{* *} \\
(0.04)\end{array}$ & $\begin{array}{l}0.34^{* * *} \\
(0.02)\end{array}$ \\
\hline R-squared & 0.96 & 0.93 & 0.84 & 0.84 & 0.96 \\
\hline \multicolumn{6}{|c|}{ Panel C: Annual Data } \\
\hline Population (log) & $\begin{array}{l}0.00 \\
(0.00)\end{array}$ & $\begin{array}{l}0.02^{\star * *} \\
(0.00)\end{array}$ & $\begin{array}{l}-0.00 \\
(0.01)\end{array}$ & $\begin{array}{l}0.00 \\
(0.01)\end{array}$ & $\begin{array}{l}0.00 \\
(0.00)\end{array}$ \\
\hline Year = 1985 & $\begin{array}{l}0.01 \\
(0.01)\end{array}$ & $\begin{array}{l}0.01^{*} \\
(0.01)\end{array}$ & $\begin{array}{l}0.07^{* * *} \\
(0.01)\end{array}$ & $\begin{array}{l}0.01 \\
(0.01)\end{array}$ & $\begin{array}{l}0.00 \\
(0.01)\end{array}$ \\
\hline Year = 1996 & $\begin{array}{l}0.03^{* * *} \\
(0.01)\end{array}$ & $\begin{array}{l}0.02^{* * *} \\
(0.01)\end{array}$ & $\begin{array}{l}0.12^{* * *} \\
(0.01)\end{array}$ & $\begin{array}{l}0.05^{\star * *} \\
(0.01)\end{array}$ & $\begin{array}{l}0.01 \\
(0.01)\end{array}$ \\
\hline Year = 2006 & $\begin{array}{l}0.04^{* * *} \\
(0.01)\end{array}$ & $\begin{array}{l}0.04^{* * *} \\
(0.01)\end{array}$ & $\begin{array}{l}0.20^{* * *} \\
(0.02)\end{array}$ & $\begin{array}{l}0.09^{* * *} \\
(0.01)\end{array}$ & $\begin{array}{l}0.03^{* * *} \\
(0.01)\end{array}$ \\
\hline Constant & $\begin{array}{l}0.37^{* * *} \\
(0.02)\end{array}$ & $\begin{array}{l}0.73^{* * *} \\
(0.03)\end{array}$ & $\begin{array}{l}0.24^{* * *} \\
(0.05)\end{array}$ & $\begin{array}{l}0.07^{*} \\
(0.04)\end{array}$ & $\begin{array}{l}0.33^{* * *} \\
(0.02)\end{array}$ \\
\hline R-squared & 0.96 & 0.93 & 0.85 & 0.84 & 0.96 \\
\hline
\end{tabular}

Notes: All regressions have 2,307 observations and control for 615 village fixed effects, with standard errors clustered at the village level. Significance levels shown are ${ }^{* * *} \mathrm{p}<0.01,{ }^{* *} \mathrm{p}<0.05$, and $* \mathrm{p}<0.1$. 
Table 6: 2SLS results for property rights on predicted village population and time

\begin{tabular}{clllll}
\hline & $\begin{array}{l}\text { Land rights } \\
\text { assigned to } \\
\text { individuals } \\
(1)\end{array}$ & $\begin{array}{l}\text { Land } \\
\text { transactions } \\
\text { occurred } \\
(2)\end{array}$ & $\begin{array}{l}\text { Pasture } \\
\text { access is } \\
\text { regulated } \\
(3)\end{array}$ & $\begin{array}{l}\text { Forest } \\
\text { access is } \\
\text { regulated } \\
(4)\end{array}$ & $\begin{array}{l}\text { Land } \\
\text { transactions } \\
\text { require permit } \\
(5)\end{array}$ \\
\hline Panel A: Post-1975 & & & & & \\
Population (log) & 0.05 & $0.13^{* * *}$ & 0.06 & $0.08^{*}$ & $-0.13^{* *}$ \\
& $(0.04)$ & $(0.04)$ & $(0.08)$ & $(0.05)$ & $(0.05)$ \\
Time = 1985-2006 & 0.01 & -0.01 & $0.11^{* * *}$ & $0.03^{*}$ & $0.05^{* * *}$ \\
& $(0.01)$ & $(0.01)$ & $(0.03)$ & $(0.02)$ & $(0.02)$ \\
\hline Panel B: Post-1985 & & & & & \\
Population (log) & $0.08^{*}$ & $0.15^{* * *}$ & $0.19^{* *}$ & 0.09 & $-0.19^{* * *}$ \\
& $(0.04)$ & $(0.05)$ & $(0.09)$ & $(0.06)$ & $(0.07)$ \\
Time = 1996-2006 & $0.03^{* * *}$ & $0.02^{* * *}$ & $0.11^{* * *}$ & $0.06^{* * *}$ & $0.03^{* * *}$ \\
& $(0.01)$ & $(0.01)$ & $(0.01)$ & $(0.01)$ & $(0.01)$ \\
\hline Panel C: Annual Data & & & & & \\
Population (log) & $0.06^{*}$ & $0.14^{* * *}$ & 0.12 & $0.09^{*}$ & $-0.16^{* * *}$ \\
& $(0.03)$ & $(0.04)$ & $(0.07)$ & $(0.05)$ & $(0.05)$ \\
Year = 1985 & -0.01 & $-0.03^{* *}$ & 0.02 & -0.02 & $0.06^{* * *}$ \\
& $(0.01)$ & $(0.01)$ & $(0.03)$ & $(0.02)$ & $(0.02)$ \\
Year = 1996 & 0.00 & $-0.03^{*}$ & $0.08^{* *}$ & 0.02 & $0.07^{* * *}$ \\
Year = 2006 & $(0.01)$ & $(0.02)$ & $(0.03)$ & $(0.02)$ & $(0.03)$ \\
& $0.04^{* * *}$ & $0.03^{* * *}$ & $0.18^{* * *}$ & $0.08^{* * *}$ & $0.04^{* * *}$ \\
& $(0.01)$ & $(0.01)$ & $(0.02)$ & $(0.01)$ & $(0.01)$ \\
\hline \hline
\end{tabular}

\footnotetext{
Notes: All regressions have 2,307 observations and control for 615 village fixed effects, with standard errors clustered at the village level. Significance levels shown are $* * * p<0.01, * * p<0.05$, and $* p<0.1$.The first stage regression for each panel is shown in Table 3.
} 
Table 7: OLS results for village population on Onchocerciasis treatment status and time, controlling for time-varying administrative region effects

\begin{tabular}{|c|c|c|c|}
\hline $\begin{array}{l}\text { Dependent variable: } \\
\text { log of village population }\end{array}$ & $\begin{array}{l}\text { Post-75 } \\
\text { (1) }\end{array}$ & $\begin{array}{l}\text { Post-85 } \\
\text { (2) }\end{array}$ & $\begin{array}{l}\text { Annual Data } \\
\text { (3) }\end{array}$ \\
\hline Treated X Post-75 (1985-2006) & $\begin{array}{l}0.29^{* *} \\
(0.12)\end{array}$ & & \\
\hline Treated X Post-85 (1996-2006) & & $\begin{array}{l}0.22^{\star \star} \\
(0.10)\end{array}$ & \\
\hline Treated X 1985 & & & $\begin{array}{l}0.19^{*} \\
(0.11)\end{array}$ \\
\hline Treated X 1996 & & & $\begin{array}{l}0.39^{* * *} \\
(0.13)\end{array}$ \\
\hline Treated X 2006 & & & $\begin{array}{l}0.29^{*} \\
(0.17)\end{array}$ \\
\hline Post-75 (1985-2006) & $\begin{array}{l}0.15 \\
(0.14)\end{array}$ & & \\
\hline Post-85 (1996-2006) & & $\begin{array}{l}-0.11 \\
(0.13)\end{array}$ & \\
\hline Year $=1985$ & & & $\begin{array}{l}0.34^{* *} \\
(0.14)\end{array}$ \\
\hline Year $=1996$ & & & $\begin{array}{l}0.25 \\
(0.16)\end{array}$ \\
\hline Year $=2006$ & & & $\begin{array}{l}-0.12 \\
(0.22)\end{array}$ \\
\hline Constant & $\begin{array}{l}6.68^{* * *} \\
(0.03)\end{array}$ & $\begin{array}{l}6.88^{* * *} \\
(0.02)\end{array}$ & $\begin{array}{l}6.68^{* * *} \\
(0.03)\end{array}$ \\
\hline R-squared & 0.05 & 0.04 & 0.13 \\
\hline
\end{tabular}

Notes: These regressions are a robustness check on Table 3, controlling for time*region fixed effects across the country's 13 administrative regions in addition to 615 village fixed effects. All regressions have 2,307 observations and standard errors are clustered at the village level. Significance levels shown are $* * * \mathrm{p}<0.01$, ** $\mathrm{p}<0.05$, and $* \mathrm{p}<0.1$ 
Table 8: OLS results for property rights on Onchocerciasis treatment status and time, controlling for time-varying administrative region effects

\begin{tabular}{|c|c|c|c|c|c|}
\hline Dependent variable: & $\begin{array}{l}\text { Land } \\
\text { rights assigned } \\
\text { to individuals } \\
\text { (1) }\end{array}$ & $\begin{array}{l}\text { Land } \\
\text { transactions } \\
\text { occurred } \\
\text { (2) }\end{array}$ & $\begin{array}{l}\text { Pasture } \\
\text { access is } \\
\text { regulated } \\
\text { (3) }\end{array}$ & $\begin{array}{l}\text { Forest } \\
\text { access is } \\
\text { regulated } \\
\text { (4) }\end{array}$ & $\begin{array}{l}\text { Land } \\
\text { transactions } \\
\text { require permit } \\
\text { (5) }\end{array}$ \\
\hline $\begin{array}{l}\text { Panel A: Post-1975 } \\
\text { Treated X Post-75 } \\
(1985-2006)\end{array}$ & $\begin{array}{l}0.04^{*} \\
(0.02)\end{array}$ & $\begin{array}{l}0.07^{* * *} \\
(0.02)\end{array}$ & $\begin{array}{l}0.06 \\
(0.04)\end{array}$ & $\begin{array}{l}0.03 \\
(0.02)\end{array}$ & $\begin{array}{l}-0.06^{* *} \\
(0.03)\end{array}$ \\
\hline Time $=1985-2006$ & $\begin{array}{l}0.00 \\
(0.03)\end{array}$ & $\begin{array}{l}-0.05^{\star *} \\
(0.02)\end{array}$ & $\begin{array}{l}0.14^{* * *} \\
(0.05)\end{array}$ & $\begin{array}{l}0.03 \\
(0.03)\end{array}$ & $\begin{array}{l}0.05^{*} \\
(0.03)\end{array}$ \\
\hline Constant & $\begin{array}{l}0.39^{* * *} \\
(0.00)\end{array}$ & $\begin{array}{l}0.84^{* * *} \\
(0.01)\end{array}$ & $\begin{array}{l}0.23^{* * *} \\
(0.01)\end{array}$ & $\begin{array}{l}0.08^{* * *} \\
(0.01)\end{array}$ & $\begin{array}{l}0.34^{* * *} \\
(0.01)\end{array}$ \\
\hline $\begin{array}{l}\text { Panel B: Post-1985 } \\
\text { Treated X Post-85 } \\
(1996-2006)\end{array}$ & $\begin{array}{l}0.04^{* *} \\
(0.02)\end{array}$ & $\begin{array}{l}0.05^{* * *} \\
(0.02)\end{array}$ & $\begin{array}{l}0.07^{* *} \\
(0.03)\end{array}$ & $\begin{array}{l}0.04 \\
(0.03)\end{array}$ & $\begin{array}{l}-0.04^{* *} \\
(0.02)\end{array}$ \\
\hline Time $=1996-2006$ & $\begin{array}{l}0.02 \\
(0.03)\end{array}$ & $\begin{array}{l}-0.03^{*} \\
(0.02)\end{array}$ & $\begin{array}{l}0.16^{\star * *} \\
(0.05)\end{array}$ & $\begin{array}{l}0.02 \\
(0.03)\end{array}$ & $\begin{array}{l}0.03 \\
(0.02)\end{array}$ \\
\hline Constant & $\begin{array}{l}0.39^{* * *} \\
(0.00)\end{array}$ & $\begin{array}{l}0.85^{\star * *} \\
(0.00)\end{array}$ & $\begin{array}{l}0.27^{\star * *} \\
(0.01)\end{array}$ & $\begin{array}{l}0.09^{* * *} \\
(0.00)\end{array}$ & $\begin{array}{l}0.34^{* * *} \\
(0.00)\end{array}$ \\
\hline \multicolumn{6}{|l|}{ Panel C: Annual Data } \\
\hline Treated X 1985 & $\begin{array}{l}0.02 \\
(0.02)\end{array}$ & $\begin{array}{l}0.05^{* *} \\
(0.02)\end{array}$ & $\begin{array}{l}0.01 \\
(0.03)\end{array}$ & $\begin{array}{l}0.01 \\
(0.01)\end{array}$ & $\begin{array}{l}-0.04 \\
(0.03)\end{array}$ \\
\hline Treated X 1996 & $\begin{array}{l}0.04 \\
(0.02)\end{array}$ & $\begin{array}{l}0.07^{\star \star \star *} \\
(0.02)\end{array}$ & $\begin{array}{l}0.07^{*} \\
(0.04)\end{array}$ & $\begin{array}{l}0.05^{*} \\
(0.03)\end{array}$ & $\begin{array}{l}-0.06^{* *} \\
(0.03)\end{array}$ \\
\hline Treated X 2006 & $\begin{array}{l}0.06^{* *} \\
(0.03)\end{array}$ & $\begin{array}{l}0.08^{* * *} \\
(0.02)\end{array}$ & $\begin{array}{l}0.09^{*} \\
(0.05)\end{array}$ & $\begin{array}{l}0.04 \\
(0.03)\end{array}$ & $\begin{array}{l}-0.06^{* *} \\
(0.03)\end{array}$ \\
\hline Year $=1985$ & $\begin{array}{l}-0.01 \\
(0.03)\end{array}$ & $\begin{array}{l}-0.04^{*} \\
(0.02)\end{array}$ & $\begin{array}{l}0.06 \\
(0.04)\end{array}$ & $\begin{array}{l}0.02 \\
(0.02)\end{array}$ & $\begin{array}{l}0.04 \\
(0.03)\end{array}$ \\
\hline Year = 1996 & $\begin{array}{l}0.02 \\
(0.04)\end{array}$ & $\begin{array}{l}-0.06^{* *} \\
(0.03)\end{array}$ & $\begin{array}{l}0.14^{* *} \\
(0.06)\end{array}$ & $\begin{array}{l}0.00 \\
(0.04)\end{array}$ & $\begin{array}{l}0.05 \\
(0.03)\end{array}$ \\
\hline Year $=2006$ & $\begin{array}{l}0.00 \\
(0.04)\end{array}$ & $\begin{array}{l}-0.05 \\
(0.03)\end{array}$ & $\begin{array}{l}0.23^{\star * *} \\
(0.07)\end{array}$ & $\begin{array}{l}0.05 \\
(0.05)\end{array}$ & $\begin{array}{l}0.06^{*} \\
(0.03)\end{array}$ \\
\hline Constant & $\begin{array}{l}0.39^{* * *} \\
(0.00)\end{array}$ & $\begin{array}{l}0.84^{* * *} \\
(0.01)\end{array}$ & $\begin{array}{l}0.23^{* * *} \\
(0.01)\end{array}$ & $\begin{array}{l}0.08^{* * *} \\
(0.01)\end{array}$ & $\begin{array}{l}0.34^{* * *} \\
(0.01)\end{array}$ \\
\hline
\end{tabular}

Notes: These regressions are a robustness check on Table 4, controlling for time*region fixed effects across the country's 13 administrative regions in addition to 615 village fixed effects. To save space, we show only coefficient estimates and standard errors for treatment variables, with full regression results available upon request. All regressions have 2,307 observations and standard errors clustered at the village level.

Significance levels shown are ${ }^{* * *} \mathrm{p}<0.01, * * \mathrm{p}<0.05$, and $* \mathrm{p}<0.1$. 
Table 9: OLS results for village population on Onchocerciasis treatment status and time, using subsamples split by distance to river

\begin{tabular}{|c|c|c|c|c|c|c|}
\hline \multirow[b]{2}{*}{$\begin{array}{l}\text { Distance to river: } \\
\text { Dependent variable: } \\
\text { log of village population }\end{array}$} & \multicolumn{2}{|c|}{$\begin{array}{c}\text { Post-75 } \\
\text { (1) }\end{array}$} & \multicolumn{2}{|c|}{$\begin{array}{c}\text { Post-85 } \\
\text { (2) }\end{array}$} & \multicolumn{2}{|c|}{$\begin{array}{c}\text { Annual Data } \\
\text { (3) }\end{array}$} \\
\hline & $\begin{array}{l}\text { Nearer } \\
\text { (a) }\end{array}$ & $\begin{array}{l}\text { Farther } \\
\text { (b) }\end{array}$ & $\begin{array}{l}\text { Nearer } \\
\text { (a) }\end{array}$ & $\begin{array}{l}\text { Farther } \\
\text { (b) }\end{array}$ & $\begin{array}{l}\text { Nearer } \\
\text { (a) }\end{array}$ & $\begin{array}{l}\text { Farther } \\
\text { (b) }\end{array}$ \\
\hline Treated X Post-75 (1985-2006) & $\begin{array}{l}0.33^{* * *} \\
(0.11)\end{array}$ & $\begin{array}{l}0.34^{* * *} \\
(0.10)\end{array}$ & & & & \\
\hline Treated X Post-85 (1996-2006) & & & $\begin{array}{l}0.20^{*} \\
(0.11)\end{array}$ & $\begin{array}{l}0.30^{* * *} \\
(0.10)\end{array}$ & & \\
\hline Treated X 1985 & & & & & $\begin{array}{l}0.26^{\star * *} \\
(0.10)\end{array}$ & $\begin{array}{l}0.21^{* *} \\
(0.10)\end{array}$ \\
\hline Treated X 1996 & & & & & $\begin{array}{l}0.42^{* * *} \\
(0.13)\end{array}$ & $\begin{array}{l}0.36^{* * *} \\
(0.11)\end{array}$ \\
\hline Treated X 2006 & & & & & $\begin{array}{l}0.31^{*} \\
(0.18)\end{array}$ & $\begin{array}{l}0.46^{* * *} \\
(0.16)\end{array}$ \\
\hline Post-75 (1985-2006) & $\begin{array}{l}0.09 \\
(0.09)\end{array}$ & $\begin{array}{l}0.09 \\
(0.08)\end{array}$ & & & & \\
\hline Post-85 (1996-2006) & & & $\begin{array}{l}-0.07 \\
(0.09)\end{array}$ & $\begin{array}{l}-0.11 \\
(0.08)\end{array}$ & & \\
\hline Year $=1985$ & & & & & $\begin{array}{l}0.19^{* * *} \\
(0.07)\end{array}$ & $\begin{array}{l}0.23^{* * *} \\
(0.07)\end{array}$ \\
\hline Year = 1996 & & & & & $\begin{array}{l}0.13 \\
(0.10)\end{array}$ & $\begin{array}{l}0.21^{* * *} \\
(0.08)\end{array}$ \\
\hline Year $=2006$ & & & & & $\begin{array}{l}-0.06 \\
(0.15)\end{array}$ & $\begin{array}{l}-0.16 \\
(0.13)\end{array}$ \\
\hline Constant & $\begin{array}{l}6.66^{* * *} \\
(0.04)\end{array}$ & $\begin{array}{l}6.70^{* * *} \\
(0.04)\end{array}$ & $\begin{array}{l}6.86^{* * *} \\
(0.03)\end{array}$ & $\begin{array}{l}6.89^{* * *} \\
(0.03)\end{array}$ & $\begin{array}{l}6.66^{\star * *} \\
(0.04)\end{array}$ & $\begin{array}{l}6.70^{* * *} \\
(0.04)\end{array}$ \\
\hline R-squared & 0.03 & 0.04 & 0.01 & 0.01 & 0.06 & 0.07 \\
\hline Observations & 1,147 & 1,160 & 1,147 & 1,160 & 1,147 & 1,160 \\
\hline Number of villages & 307 & 308 & 307 & 308 & 307 & 308 \\
\hline Baseline & 1975 & 1975 & $1975-1985$ & $1975-1985$ & 1975 & 1975 \\
\hline
\end{tabular}

Notes: All regressions divide the sample into the half of villages that are nearer (a) or farther (b) from a river, and control for village fixed effects with standard errors clustered at the village level. Significance levels shown are $* * * \mathrm{p}<0.01,{ }^{* *} \mathrm{p}<0.05$, and $* \mathrm{p}<0.1$. 
Table 10: OLS results for property rights on Onchocerciasis treatment status and time, using subsamples split by distance to river

\begin{tabular}{|c|c|c|c|c|c|}
\hline $\begin{array}{l}\text { Dependent variable: } \\
\text { Distance to river: }\end{array}$ & $\begin{array}{l}\text { Land } \\
\text { rights assigned } \\
\text { to individuals } \\
\text { (1) }\end{array}$ & $\begin{array}{l}\text { Land } \\
\text { transactions } \\
\text { occurred } \\
\text { (2) } \\
\end{array}$ & $\begin{array}{l}\text { Pasture } \\
\text { Access is } \\
\text { regulated } \\
(3)\end{array}$ & $\begin{array}{l}\text { Forest } \\
\text { Access is } \\
\text { regulated } \\
\text { (4) }\end{array}$ & $\begin{array}{l}\text { Land } \\
\text { transactions } \\
\text { require permit } \\
\text { (5) }\end{array}$ \\
\hline \multicolumn{6}{|l|}{ Panel A: Post-1975 } \\
\hline (a) Nearer to rivers & $\begin{array}{l}0.03^{* *} \\
(0.01)\end{array}$ & $\begin{array}{l}0.06^{\star * *} \\
(0.02)\end{array}$ & $\begin{array}{l}0.02 \\
(0.04)\end{array}$ & $\begin{array}{l}0.04^{* *} \\
(0.02)\end{array}$ & $\begin{array}{l}-0.03 \\
(0.02)\end{array}$ \\
\hline (b) Farther from rivers & $\begin{array}{l}0.00 \\
(0.02)\end{array}$ & $\begin{array}{l}0.03^{* *} \\
(0.01)\end{array}$ & $\begin{array}{l}0.02 \\
(0.04)\end{array}$ & $\begin{array}{l}0.01 \\
(0.02)\end{array}$ & $\begin{array}{l}-0.06^{* * *} \\
(0.02)\end{array}$ \\
\hline \multicolumn{6}{|l|}{ Panel B: Post-1985 } \\
\hline (a) Nearer to rivers & $\begin{array}{l}0.03^{*} \\
(0.01)\end{array}$ & $\begin{array}{l}0.04^{* * *} \\
(0.01)\end{array}$ & $\begin{array}{l}0.04 \\
(0.03)\end{array}$ & $\begin{array}{l}0.05^{*} \\
(0.03)\end{array}$ & $\begin{array}{l}-0.02 \\
(0.02)\end{array}$ \\
\hline (b) Farther from rivers & $\begin{array}{l}0.02 \\
(0.02)\end{array}$ & $\begin{array}{l}0.03^{* *} \\
(0.02)\end{array}$ & $\begin{array}{l}0.05^{*} \\
(0.03)\end{array}$ & $\begin{array}{l}0.00 \\
(0.03)\end{array}$ & $\begin{array}{l}-0.07^{\star * \star} \\
(0.02)\end{array}$ \\
\hline \multicolumn{6}{|l|}{ Panel C: Annual Data } \\
\hline \multicolumn{6}{|l|}{ (a) Nearer to rivers } \\
\hline Treated X 1985 & $\begin{array}{l}0.02 \\
(0.01)\end{array}$ & $\begin{array}{l}0.05^{\star *} \\
(0.02)\end{array}$ & $\begin{array}{l}-0.01 \\
(0.03)\end{array}$ & $\begin{array}{l}0.02 \\
(0.01)\end{array}$ & $\begin{array}{l}-0.02 \\
(0.02)\end{array}$ \\
\hline Treated X 1996 & $\begin{array}{l}0.02 \\
(0.01)\end{array}$ & $\begin{array}{l}0.05^{\star * *} \\
(0.02)\end{array}$ & $\begin{array}{l}0.03 \\
(0.04)\end{array}$ & $\begin{array}{l}0.05^{*} \\
(0.03)\end{array}$ & $\begin{array}{l}-0.03 \\
(0.02)\end{array}$ \\
\hline Treated X 2006 & $\begin{array}{l}0.05^{* *} \\
(0.02)\end{array}$ & $\begin{array}{l}0.08^{* * *} \\
(0.02)\end{array}$ & $\begin{array}{l}0.05 \\
(0.05)\end{array}$ & $\begin{array}{l}0.07^{* *} \\
(0.03)\end{array}$ & $\begin{array}{l}-0.03 \\
(0.03)\end{array}$ \\
\hline \multicolumn{6}{|l|}{ (b) Farther from rivers } \\
\hline Treated X 1985 & $\begin{array}{l}-0.02 \\
(0.02)\end{array}$ & $\begin{array}{l}0.01 \\
(0.01)\end{array}$ & $\begin{array}{l}-0.02 \\
(0.03)\end{array}$ & $\begin{array}{l}0.02 \\
(0.01)\end{array}$ & $\begin{array}{l}-0.02 \\
(0.02)\end{array}$ \\
\hline Treated X 1996 & $\begin{array}{l}0.00 \\
(0.02)\end{array}$ & $\begin{array}{l}0.02 \\
(0.02)\end{array}$ & $\begin{array}{l}0.03 \\
(0.04)\end{array}$ & $\begin{array}{l}0.01 \\
(0.03)\end{array}$ & $\begin{array}{l}-0.06^{* * *} \\
(0.02)\end{array}$ \\
\hline Treated X 2006 & $\begin{array}{l}0.01 \\
(0.03)\end{array}$ & $\begin{array}{l}0.06^{* * *} \\
(0.02)\end{array}$ & $\begin{array}{l}0.05 \\
(0.05)\end{array}$ & $\begin{array}{l}0.01 \\
(0.03)\end{array}$ & $\begin{array}{l}-0.11^{* * *} \\
(0.03)\end{array}$ \\
\hline
\end{tabular}

Notes: All regressions divide the sample into the half of villages that are nearer (a) or farther (b) from a river, and control for village fixed effects with standard errors clustered at the village level. To save space, we show only coefficient estimates and standard errors for treatment variables, with full regression results available upon request. As with Table 9, the nearer and farther subsamples have 307 and 308 villages, for a total of 1147 and 1160 observations respectively. Significance levels shown are ${ }^{* *} \mathrm{p}<0.01,{ }^{* *} \mathrm{p}<0.05$, and ${ }^{*} \mathrm{p}<0.1$. 